\title{
Elegia na progu. Antyczne dziedzictwo motywu paraklausithyron w twórczości elegijnej renesansu (usque ad Ioannem Cochanovium)
}

Przedmiotem niniejszego studium jest paraklausithyron ${ }^{\mathrm{I}}$ - forma ponadgatunkowa, wywodząca się z greckiego archaicznego gatunku zwanego komos, która $\mathrm{z}$ czasem - na prawach wędrownego motywu literackiego - weszła do innych form gatunkowych, w okresie rzymskim najsilniej zrastając się z elegią. Większość badaczy (Howard Vernon Canter czy Frank Copley) uznaje paraklausithyron za motyw czy temat literacki, podkreślając, że nie jest to osobny gatunek, lecz może on występować we wszystkich utworach, których tematyka związana jest z miłością ${ }^{2}$. Są jednak i inne ujęcia: na przykład Francis Cairns ${ }^{3}$ dla wszystkich postaci paraklausithyronu - niezależnie od języka i formy, w jakiej występuje - konsekwentnie używa określenia „komos”. Wynika to z założenia jego książki, klasyfikującej grecko-rzymską literaturę według najstarszych pierwotnych form gatunkowych. Dla spójności terminologicznej poniższego wywodu określam paraklausithyron jako motyw literacki, ze świadomością jednak, że stał się on podstawą nowożytnych form gatunkowych, takich jak na przykład serenada. O jego specyfice czy odrębności od innych form literackich nie decyduje ani forma podawcza (występuje bowiem we wszystkich rodzajach li-

I Termin ten, niezakorzeniony jeszcze w polszczyźnie, odmieniam podobnie jak inne wyrazy greckie zakończone na -on (epicedion, gimnazjon, dendron, propemptikon), tj. w mianowniku liczby pojedynczej parklausithyron, mnogiej - paraklausithyra, zaś końcówki pozostałych przypadków - zgodnie z fleksją polską - od tych dwóch podstaw mianownikowych (por. w epicediach, o gimnazjach).

${ }^{2}$ F. Copley, Exclusus Amator. A Study in Love Poetry, Oxford 1956, s. 1; H.V. Canter, The Paraclausithyron as a Literary Theme, „American Journal of Philology" 1920, t. 41, nr 4, s. 355-368 - tu również przedstawienie dyskusji nad etymologią wyrazu.

3 F. Cairns, Generic Composition in Greek and Roman Poetry, Edinburgh 1972. 
terackich), ani też postać metryczna czy stylistyczna, lecz temat bądź przywoływany obraz: scenka nocnego śpiewu pod drzwiami dziewczyny - budowane przez zespół charakterystycznych topoi. Topoi te z czasem emancypują się od pierwotnie dramaturgicznej formy komosu i jako loci communes, słowa klucze (jak drzwi, próg, wieniec etc.) substytuują paraklausithyron, uruchamiając zespół zaprogramowanych tak skojarzeń literackich $\mathrm{w}$ dowolnej formie gatunkowej.

Przedstawienie klasycznej postaci paraklausithyronu, ze szczególnym podkreśleniem jego zastosowania w elegii, ma tu stanowić podstawę analizy renesansowej formy paraklausithyronu elegijnego - zwłaszcza dzieł Jana Kochanowskiego, wpisujących się w tę formę - zarówno w poezji łacińskiej, jak i polskiej.

\section{Na progu...}

W utworze otwierającym trzecią księgę elegii Owidiusza alegoryczne postacie Tragedia i Elegia walczą o talent poety i patronat nad jego twórczością. Powabna Elegia (nierówność stóp nawet przydawała jej uroku ${ }^{4}$ ) wyraźnie zwycięża potyczkę słowną z królewską, odzianą w purpurę i stąpającą na koturnach Tragedią, mimo swojej niewątpliwej niższości w hierarchii gatunków. Tę różnicę poeta obrazuje symbolicznie:

non ego contulerim sublimia carmina nostris; obruit exiguas regia vestra fores.

sum levis, et mecum levis est, mea cura, Cupido; non sum materia fortior ipsa mea.

(Ovid.Am. III 1, 39-42)

Nie porównywałabym wzniosłych pieśni do moich, twój królewski pałac usuwa w cień niepozorne drzwi.

Płocha jestem, jak i ten, o którego się troszczę, płochy jest Kupido, i sama nie jestem poważniejsza od materii, którą podejmuję5.

4 Dystych elegijny uznawano niekiedy za ułomny, „kulawy” heksametr, ponieważ jego drugi wers, pentametryczny, miał być heksametrem daktylicznym pozbawionym jednej stopy. Zabawne rozwinięcie tego konceptu - zob. Owidiusz, Amores (elegia I 1, 1-4).

5 Cytacje z literatury klasycznej przytaczam za wydaniami z serii „Loeb Classical Library”. Jeśli nie opisano inaczej, przekłady pochodzą od autorki artykułu. Podobnie - wszystkie wyróżnienia fragmentów w cytowanych tekstach. W artykule użyto następujących skrótów tytułów utworów klasycznych i renesansowych (stojące po siglum cyfry rzymskie oznaczają numer księgi, arabskie - numer wersu): Cat. - Catullus, Carmina; Hor.Ars Poet. - Horatius, 
Czym podyktowane jest tak dziwne ujęcie, dlaczego tragedię symbolizuje pałac, a elegię - drzwi? Ujęcie, na pierwszy rzut oka, na tyle zaskakujące, że autorka polskiego przekładu, Anna Świderkówna, zmieniła owe drzwi na... chatkę: „Któż by śmiał z twoją pieśnią równać moje pienia: / Moją chatkę królewski twój pałac zacienia" ${ }^{6}$. Gdy jednak odczytamy ten tekst w kontekście greckiego motywu paraklausithyron 7 (w wersji łacińskiej exclusus amator), sprawa staje się jasna. O ile bowiem tragedie, przedstawiające wielkość i upadek władców, zazwyczaj rozgrywają się przed królewskimi pałacami, o tyle akcja elegii ma miejsce zwykle przed drzwiami - na głucho zamkniętymi przed niecierpliwym, zazdrosnym kochankiem, który śpiewem, a czasem i przemocą, usiłuje dotrzeć do dziewczyny.

$\mathrm{Na}$ tenże motyw wskazuje Owidiusz już w następnych wersach: „quam tu non poteris duro reserare cothurno,/ haec est blanditiis ianua laxa meis” („te drzwi, których nie odryglowałabyś na twoich twardych koturnach, / otwierają się przed moimi powabami”, w. 45-46) - kontynuuje swój wywód Pani Elegia, a jej słowa odnoszą się zapewne do stylu. Oddając oponentce sprawiedliwość w zakresie rangi, powagi poruszanych tematów, podkreśla jednak jeszcze swoją rolę kulturotwórczą - pieśń miłosna bowiem uśmierza dzikość popędów: „rustica sit sine me lascivi mater Amoris” ("wiejską prostaczką byłaby beze mnie matka swawolnego Amora”, w. 43). Opinię tę powtórzy poeta jeszcze w aitiologicznym wywodzie w Fasti, gdzie doszukując się źródeł obyczajów i kultów bóstw, tłumaczy wielką cześć, jaką cieszy się bogini Miłości. Wenera mianowicie ma największą moc twórczą - jest źródłem życia oraz sztuki. Powstanie pieśni, sztuki poetyckiej łączy tu Owidiusz z ludzką potrzebą ekspresji uczuć i znalezienia środków perswazyjnych - a wszystko to dokonało się pod zamkniętymi drzwiami ukochanej:

primus amans carmen vigilatum nocte negata

dicitur ad clausas concinuisse fores,

$\overline{\text { Ars Poetica; Hor.Od. }}$ - Horatius, Odae (Carmina); Ov.Am. - Ovidius, Amores; Ov.Ars.am. - Ovidius, Ars amatoria; Ov.Met. - Ovidius, Metamorphoses; Ov.Fasti - Ovidius, Fasti; Ov.Rem.am. - Ovidius, Remedia amoris; Plaut. Curc. - Plautus, Curculio; Prop. - Propertius, Elegiae; Tib. - Tibullus, Elegiae; Koch.El. - Jan Kochanowski, Elegiarum libri quattuor; Koch.Pieśni - Jan Kochanowski, Pieśni ksiag dwoje; Pont.Parth. - Giovanni Pontano, Parthenopeus sive Amores.

${ }^{6}$ Rzymska elegia miłosna (wybór), przeł. A. Świderkówna, oprac. G. Przychodzki, W. Strzelecki, Wrocław 1955, s. 148.

7 Zwraca na to uwagę F. Copley - zob. F. Copley, op.cit., s. 82-85. 
eloquiumque fuit duram exorare puellam, proque sua causa quisque disertus erat.

(Ov.Fasti, IV 109-112)

Jak wieść niesie, pierwszy odśpiewał pieśń oczekiwania kochanek pod zamkniętymi drzwiami, gdy mu nocy odmówiono - żeby przejednać nieprzystępną dziewczynę wymową, bo każdy w swojej sprawie stawał się wymowny.

Dla Owidiusza, ostatniego z wielkiej trójcy elegików, zbierającego i podsumowującego doświadczenia poprzedników, sposoby literackiego formułowania uczucia w tym gatunku były już w takim stopniu skonwencjonalizowane, że opis zachowania komastycznego wszedł do sformułowanego przezeń instruktarzu dla kochanka - pragnącego pozyskać miłość, albo się jej wyzbyć. W jego dwu parodiach poematu dydaktycznego, Ars amatoria oraz Remedia amoris, pieśń pod zamkniętymi drzwiami odgrywa istotną rolę (zob. Ars.am. II 523-528; 579-588; Rem. am. 29-36; 505-512). W cytowanej wyżej elegii (podobnie jak w kilku innych) motyw pieśni pod drzwiami zyskuje zaś pozycję centralną wśród motywów elegijnych.

Pieśń miłosna, a nawet sama miłość w poezji rzymskiej najczęściej wyrażana jest właśnie przez obraz vigilatio ad clausas fores (czuwanie pod zamkniętymi drzwiami). Motyw ów na tyle silnie wszedł do języka poezji, że nierzadko samo pojawienie się $\mathrm{w}$ tekście drzwi, bramy (fores, ianua) czy progu (limen), względnie rygla (pessulus) oznacza miłość, jest jej słownym i obrazowym substytutem (zob. Hor.Od. I 25; II 10 - by posłużyć się przykładem nieelegijnym), a już choćby nadmienienie o ryglu, łomie, wieńcu na drzwiach czy spaniu na progu wskazuje na miłosny temat twórczości (np. Hor. Od. III 26, 7-8). Najsilniej jednak ów motyw złączył się z miłością elegijną. W elegii epoki augustowskiej śpiewne czuwanie pod zamkniętymi drzwiami kochanki stanowi kwintesencję miłości.

Jak dowodzi autor najpełniejszego opisu motywu, Frank Copley, w książce Exclusus Amator. A Study in Love Poetry, wśród motywów elegii rzymskiej paraklausithyron zyskuje rolę wiodącą. Lament kochanka pozostawionego za zamkniętymi drzwiami jest dla nich pierwszym, podstawowym i najbardziej charakterystycznym sposobem wyrażania miłości - jak również jej objawem, a jako taki staje się środkiem obrazowania miłości wszechogarniającej człowieka, dominującej i podporządkowującej sobie jego życie ${ }^{8}$.

\footnotetext{
${ }^{8}$ Por. ibidem, s. 70.
} 


\section{Elegijny „system” miłości}

Opisy nieposkromionej ludzkiej emocjonalności w literaturze greckiej mają długą tradycję. W epoce archaicznej człowiecza podległość bezwzględnej, nieprzezwyciężonej mocy bóstw miłości - dająca równocześnie rozkosz i cierpienie - znalazła niezwykle subtelny wyraz artystyczny w liryce Safony. W epoce klasycznej, w tragediach Eurypidesa, uczucie to - w skrajnej, patologicznej postaci manii, szaleństwa prowadzącego do samozniszczenia - poddane zostało wnikliwej analizie filozoficznej i psychologicznej. Epoka hellenistyczna tworzy na wskroś literacki, od początku zaszyfrowany portret pasterza-poety-kochanka, którego nieszczęśliwa miłość wiedzie na skraj śmierci. Można jednak śmiało wysunąć tezę, że dopiero rzymska elegia tworzy, za pomocą środków wypracowanych przez poprzedników, pierwszy system miłości skonwencjonalizowanej ${ }^{9}$, pierwszy literacki system mówienia o miłości jako wszechogarniającym uczuciu "totalnym” " ${ }^{\text {o }}$, podporządkowującym sobie całe życie kochającego, wszystkie jego myśli, działania, a nawet samą wolę życia lub jej brak, prowadząc niekiedy do samobójczej śmierci. A czyni to za pomocą określonego kodu, zbioru motywów, rekwizytów, loci communes.

System elegijny da z kolei impuls do powstania w określonych warunkach kulturowych następnych wielkich systemów skonwencjonalizowanego odczuwania i opisywania miłości o wymiarze totalnym: system miłości rycerskiej (XII w.), petrarkistowskiej (głównie XVI w.) oraz romantycznej (XIX w.). I chyba należałoby dodać do tego jeszcze jeden - pastoralnej, który zdominował wieki XVII i XVIII. Wprawdzie źródła poezji pastoralnej, jak wspomniano wyżej, są starsze (wiele zawdzięcza

9 Leonard Forster na początku swego kanonicznego już studium The Icy Fire. Five Studies in European Petrarchism (Cambridge 1969, s. 2) wysunął tezę - idąc śladami Hansa Pirytza - że petrarkizm „stał się drugim wielkim międzynarodowym systemem skonwencjonalizowanej miłości, pomiędzy miłością rycerską w średniowieczu a romantyczną w wiekach XVIII i XIX”. Wydaje mi się zasadne rozwinięcie tej koncepcji i włączenie w jej obręb literatury klasycznej, z której wyrasta analizowana przez Forstera - średniowieczna i nowożytna. O rzymskim elegijnym „systemie miłości” pisze też F. Copley (op.cit., s. VIII i n.). System skonwencjonalizowanego miłowania przedstawiają również: C.S. Lewis, Alegory of Love. A Study of Medieval Tradition, Oxford 1985; D. de Rougemont, Mity o miłości, przeł. M. Żurowska, Warszawa 2002. Skonwencjonalizowane sposoby opisywania miłości, kształtujące zachowania ludzkie, omówił u nas Jerzy Adamski w książce Modele miłości i wzory człowieczeństwa. Szkice z literatury woskiej, Kraków 1974.

то O takim „totalnym” wymiarze miłości elegijnej wspomina wielokrotnie F. Copley. 
im elegia rzymska), jednak na tym etapie ukształtowana została również przez literaturę nowożytną, w tym elegię. Co znamienne, tak skonwencjonalizowanego systemu nie stworzyły literackie nurty, nazwijmy je, eudajmonistyczne czy hedonistyczne. Zapewne dlatego, że miłość jest tam narzędziem osiągania przyjemności, rozkoszy, nie podporządkowuje sobie - jak tamte całego człowieka, jego myśli, uczuć, działań, życia (ze śmiercią). Tu człowiek podporządkowuje sobie miłość, tam - ona jego.

$\mathrm{W}$ wymienionych systemach pragnienie rozkoszy, chęć zaspokojenia żądz przeplata się ze swoistym sentymentalizmem, mistycyzmem, sakryfikowaniem uczucia i jego przedmiotu. Stosownie do tego wykorzystywane są i środki wyrazu, czerpane z wielu konwencji i gatunków. Będąc pierwszym z nich, system elegijny wypracował, a właściwie zestawił z sobą, skompilował znaczną część wykorzystywanych później narzędzi.

Jednym $\mathrm{z}$ takich motywów o wysokim stopniu skonwencjonalizowania, podlegających wręcz emblematyzacji, jest klasyczny paraklausithyron. Motyw, który wraz ze sposobami odczuwania i wyrażania miłości „szlachetnieje” z upływem czasu i epok ${ }^{\mathrm{II}}$. Jego literacka historia wiedzie od komediowego opisu pijackich burd pod domami nierządu do najsubtelniejszych westchnień romantycznego kochanka, który nie mając odwagi na śmiałe wyznanie, śle pieśni pod oknem pani, albo tylko tęskne myśli - tak ciche, by nie zbudzić wybranki ${ }^{12}$. Zanim jednak pieśn pod zamkniętymi drzwiami, oknem lub balkonem ukochanej spod lupanaru wkroczyła do renesansowej serenady czy liryków poetów romantyzmu, musiała przejść swoisty czyściec w elegii.

II Gwoli ścisłości należy zaznaczyć, że ta wysubtelniona, „romantyczna” czy „sentymentalna” wersja paraklausithyronu pojawiła się już na początku jego literackiego istnienia, a mianowicie w idylli 3 Teokryta, zatytułowanej Komos, będącej w istocie parodią owego komediowego motywu. Tęskny pasterz śpiewa, stojąc przed grotą, w której schroniła się pasterka Amarylis (zob. polski przekład, zatytułowany Serenada pasterska, w: Sielanka grecka. Teokryt i mniejsi bukolicy. Z dodatkiem: Bukolika grecka w Polsce, przeł. A. Świderkówna, oprac. J. Łanowski, Wrocław 1953). Piękną parafrazę tego utworu włączył Szymon Szymonowic do sielanki Zalotnicy: pasterz-komasta czuwa u wejścia do groty, strzegąc snu pięknej Neery, którą chciałby poślubić - ten utwór jest już prawdziwą „, sentymentalną” serenadą.

${ }^{\text {I2 }}$ Zob. np. E.A. Poe, Serenade (1833). Zbieżność serenad epoki romantyzmu - tkwiących jeszcze głęboko w liryce sentymentalnej, bardzo przecież mocno związanej z poezją pastoralną - ze wspomnianą idyllą Teokryta jest uderzająca. Nim jednak odruchowo połączy się je ze sobą, należy jeszcze wziąć pod uwagę pośredniczącą między nimi tradycję elegijną. 


\section{Paraklausithyron komediowy}

Grecki paraklausithyron (pieśń kochanka pod zamkniętymi drzwiami), nim stał się konstytutywnym elementem elegii, pierwotnie był motywem dramaturgicznym, komediowym, wywodzącym się z archaicznego gatunku komos - opisującego hałaśliwy pochód biesiadników rozochoconych po uczcie (spędzanej w męskim gronie). Wracający przez uśpione ulice miasta kończyli przemarsz pod domem nierządu (lupanar $\left.{ }^{13}\right)$, gdzie stręczyciel (leno) trzymał piękne niewolnice, z których wdzięków żył. Takie nocne wyprawy kończyły się zwykle niepowodzeniem: wrota były na głucho zamknięte, a pijany amant zmęczony bezskutecznym dobijaniem się i pieśnią bez odzewu wieszał biesiadny wieniec na odrzwiach jako świadectwo swego nocnego czuwania, całował próg i odchodził, żaląc się na swój los, zimny wiatr czy deszcz oraz nieustępliwość nieczułej dziewczyny, albo też znużony zasypiał na progu - chyba że poszczuto go psami lub pogoniono kijami.

Najstarsze greckie realizacje motywu zachowały się w epigramacie, głównie hellenistycznym (Antologia Palatyńska) oraz zwykle w formie sparodiowanej, w komedii. Można tu wymienić Eurypidesowy dramat satyrowy $C y k l o p^{\mathrm{I}} 4$ (w. 495-502; Odys przed oślepieniem Polifema upija go, lecz ryki prostaka rażą go do tego stopnia, że widzi potrzebę nauczenia grubianina stosownej do okoliczności pieśni - komosu) czy przedstawiający całą scenę pod drzwiami Sejm kobiet ${ }^{15}$ Arystofanesa (w. 938-975; akcja komedii zaburza jednak schemat komosu - role się odwracają w nieprzewidziany przez amanta sposób). W bukolice Teokryta pojawia się paraklausithyron sparodiowany - przeniesiony z miasta w przestrzeń pasterską (idylla 3), a także nadmorską (idylla 11 $\left.{ }^{\mathrm{I} 6}\right)$. Najwyraźniej motyw ów już wówczas musiał być znacznie zużyty, dlatego też dość trudno było go wykorzystywać bez ironicznego cudzysłowu. Bardziej nienaruszony okazuje się

I3 Przytaczam tu łacińskie, nie greckie nazwy, by wprowadzić terminologię, którą posługuje się elegia rzymska i renesansowa.

${ }^{I} 4$ Przekład polski: Eurypides, Tragedie, przełożył, wstępem i przypisami opatrzył J. Łanowski, przekład przejrzała J. Ławińska-Tyszkowska, t. 4, Warszawa 2007.

${ }^{15}$ Polska wersja: Arystofanes, Komedie, przełożyła, wstępem i przypisami opatrzyła J. Ławińska-Tyszkowska, t. 2, Warszawa 2003.

${ }^{16}$ Nader ciekawe odczytanie idylli 11 jako komosu przedstawia F. Cairns (op.cit, s. 143-147). Wydaje się zresztą, że koncept Teokryta - Polifem starający się o względy nereidy Galatei stoi „u wrót” jej domu, czyli na brzegu morza, i daremnie wyśpiewuje tęskne pieśni - mógł być zainspirowany wspomnianym fragmentem z Eurypidesowego Cyklopa. 
$\mathrm{w}$ formach zawierających wyznanie liryczne. Motyw exclusus amator sprawdza się bowiem przede wszystkim w lamentacjach miłosnych, z czasem, już w elegii rzymskiej, stając się figurą nieodwzajemnionej, przynoszącej cierpienie miłości - a ta wszak będzie uczuciem opisywanym we wspomnianym gatunku.

Grecki paraklausithyron niedramatyczny - już w oderwaniu od komediowej scenki pod lupanarem - był zwykle skargą nieszczęśnika na cierpienia, jakie zadaje mu Eros, rażąc go strzałami i paląc ogniem. Żalący się kochanek jest bezwolny wobec tego wszechmocnego bóstwa - a gdy jeszcze zawładnie nim Bakchus, nie ma szans na wyzwolenie z ich mocy. Ból wywołuje łzy, prowadzi niekiedy na skraj szaleństwa. Dziewczyna, która broni mu wstępu, jest bezwzględna i okrutna, jakby rodziła ją lwica, jej serce - twarde jak kamień, a nadto gotowa jest do zdrady. W greckiej wersji nie ma jednak miejsca na pragnienie zemsty czy oskarżenia kierowane wprost do niej - tęskne westchnienia i prośby o litość mogą być wzmocnione jedynie próbami zastraszenia dziewczyny wizją nadchodzącej starości, młodość bowiem przemija i trzeba kochać póki czas. W końcu niewczesny amant wiesza wieniec biesiadny na drzwiach, całuje próg i odchodzi albo na nim zasypia ${ }^{17}$.

Nowe życie zaczyna paraklausithyron w Rzymie - i to, chciałoby się rzec, w prawidłowej kolejności, poczynając od komedii, by przejść do liryki. Najpełniejszą komediową postać, niosąca już typowe cechy rzymskiej wersji motyw exclusus amator zyskuje w Curculio Plauta ${ }^{18}$. Pierwszy akt tej sztuki przedstawia rozbudowaną scenę pod drzwiami - błagania amanta uzupełniają tu komiczne komentarze jego sługi. Rzymski paraklausithyron ma tyle specyficznych właściwości, różnych od greckiego, że - jak się przypuszcza - grecki wzorzec musiał znaleźć podatny grunt $\mathrm{w}$ rodzimej obyczajowości oraz tradycji pieśniowej (zapewne istniała italska „ludowa" piosenka uliczna ${ }^{\text {I9 }}$ ).

Jedną z takich wyróżniających rzymski komos cech jest dominująca rola drzwi, które stają się podmiotem, adresatem, a czasem i osobą mówiącą. Wiązać to należy z niezwykle rozbudowaną symboliką drzwi w religii i kulturze rzymskiej ${ }^{20}$. Ten

${ }_{77}$ Zob. F. Copley, op.cit., rozdz. 1-2, zwłaszcza s. 19-20. Autor przytacza jeszcze wiele greckich opisów zachowań komastycznych (s. 22-26).

I8 Polska wersja: T. Maccius Plautus, Komedie, przełożył, wstępem, streszczeniami opatrzył G. Przychodzki, t. 4, Kraków 1937.

I9 F. Copley, op.cit., s. 28-33 i n.; tu również polemika z wcześniejszymi odmiennymi opiniami na temat rzymskich źródeł piosenki przed drzwiami.

${ }^{20} \mathrm{Na}$ temat symboliki drzwi w religii rzymskiej - zob. H.H. Scullard, $\mathrm{Fe}$ stival and Ceremonies of the Roman Republic, Ithaca 1981, s. 13-41; w rzymskim 
związek świetnie obrazuje wspomniana komedia Plauta, w której bohater, Phaedromus, chcąc obłaskawić oddzielające go od ukochanej drzwi, używa liturgicznych formuł modlitewnych wypowiadanych w czasie składania obiaty bóstwu wrót, Janusowi: „Agite, bibite, festivae fores; / potate, fite mihi volentes propitiae!” (Poruszcie się, pijcie, miłe drzwi, / spijajcie, bądźcie mi przychylne i życzliwe!” ${ }^{21}$, w. 88-89). Podobnie pieśń Phedromusa do zawartych rygli (w. 147-154) ${ }^{22}$, która nosi cechy carmen magicum - magiczne zaklęcia mają otworzyć dostęp do wnę$\operatorname{trza}^{23}$. Zatem personifikacja drzwi w łacińskich komosach (często kochanek śpiewa nie tyle pod drzwiami, co do drzwi) znana z Katullusa (carmen 67 - dialog przechodnia z drzwiami), Propercjusza (elegia I 16 - skarga bramy) czy na gruncie polskim z Kochanowskiego (pieśń I 25) - ma swoje źródła w rzymskiej obyczajowości i literaturze okresu archaicznego.

Świadectwem ciąłości tradycji komastycznej w Rzymie republikańskim - przed rozkwitem liryki w epoce augustowskiej - jest fragment z De rerum natura (IV 1177-1179) Lukrecjusza, potępiającego sprośne obyczaje miłosne Rzymian (a zwłaszcza płci niewieściej):

at lacrimans exclusus amator limina saepe

floribus et sertis operit postisque superbos

unguit amaracino et foribus miser oscula figit;

domu - E.H. Haight, The Symbolism of House Door in Classical Poetry, New York 1950, zwłaszcza rozdz. 4.

${ }^{2 I}$ Przekład Przychodzkiego nie oddaje podniosłego, prekacyjnego charakteru wezwania, w oryginale kontrastującego z prześmiewczymi komentarzami niewolnika Palinurusa: „Fedromus: «No, pijcie, miłe drzwiczki, no popijcie sobie,/ I bądźcie mi przychylne!» Palinurus: «A może oliwek, / Może mięsnej potrawki, a może kaparków? »" (s. 103).

${ }_{22}$ „Pessuli, heus pessuli, vos saluto lubens, / vos amo, vos volo, vos peto atque obsecro, / gerite amanti mihi morem, amoenissumi, / fite causa mea ludii barbari, / sussilite, obsecro, et mittite istanc foras, / quae mihi misero amanti ebibit sanguinem./ hoc vide ut dormiunt pessuli pessumi / nec mea gratia commovent se ocius./ re spicio, nihili meam vos gratiam facere”. Przekład Przychodzkiego (poprzedzający wspomniane badania nad tekstem) jest konsekwentnie utrzymany w stylistyce komediowej: „Hej wy, rygle, hej wy rygle, / Was witam tak czule, / Dla was myśli me, uczucia, / Was proszę i błagam!/ A spełnijcie moją prośbę,/ Bom jest zakochany:/ Wy najdroższe, bądźcie dla mnie/ Skoczkami rzymskimi/ I odskoczcie - tak was błagam - / I na dwór wypuście/ Tę, co mnie nieszczęśliwemu,/ Krew z serca wypija!/Ale patrz, patrz, jak śpią sobie/ Te brzydkie rygliska/ I nie myślą wcale dla mnie/ Poruszyć się żwawiej!/ Najdokładniej widzę teraz, / Że o mnie nie dbacie!” (s. 110-111).

${ }_{23}$ Wcześniejsze badania nad religijnymi źródłami wspomnianych fragmentów Curculia zbiera F. Copley, op.cit., s. 28-32. 
A wypędzony kochanek, zalany łzami, nierzadko

Próg obsypuje kwiatami, namaszcza wonnym olejkiem

Wyniosłe odrzwia, wyciska, biedak, na drzwiach pocałunki ${ }^{24}$.

\section{W rzymskiej poezji augustowskiej}

W I w. p.n.e., jak konstatuje Copley, istniały trzy wersje motywu, pochodzące $\mathrm{z}$ różnych źródeł, lecz wkrótce połączone $\mathrm{w}$ bujnie rozwijającej się nowej liryce. Prócz klasycznego literackiego wzorca greckiego, były to: paszkwil na obyczaje, piętnujący głównie kazirodztwo i zdradę małżeńską (typ diffamatio - osławienie), oraz wulgarna piosenka uliczna. Poezja neoteryków, szukających wciąż nowych źródeł i form ekspresji zarówno w uczonej poezji aleksandryjskiej, jak i (też za przykładem aleksandryjczyków) w tradycjach ludowych, połączyła te typy. U Katullusa bowiem (carmen 67 - paraklausithyron w postaci diffamatio - upersonifikowane drzwi ślą skargę na obyczaje domowników) dostrzec można próbę - w ramach konwencjonalnego greckiego motywu - nadania rodzimej obscenicznej piosence spod lupanaru formy literackiej, mieszczącej się $\mathrm{w}$ modelu poesia docta. Innym przykładem będzie tu fraszka (łac. nugae) 32: do pięknej nierządnicy poeta kieruje prośbę o nieryglowanie drzwi, by mógł spędzić rozkoszne popołudnie w jej ramionach.

Kolejnych eksperymentów z paraklausithyronem dokonywał Horacy - zarówno w lirycznych odach (I 25; III 7; 10; 26), jak i paszkwilanckich satyrach (I 2, 64-67; 4, 48-52; 5, 14ff; II 3, 258-264) czy epodzie 11. Fragmenty satyrowe mieszczą się zwykle w typie diffamatio, w liryce jednak, co znamienne i mające swe konsekwencje, Horacy swobodnie miesza te typy. Widać tu także tendencję do emblematyzacji motywu, jego uproszczenia czy substytucji jego składowych, tak by samo pojawienie się któregoś ze słów kluczy pociągało za sobą skojarzenie z całym motywem i wszystkimi okolicznościami, w jakich zwykle on się pojawia.

${ }_{24}$ Titus Lucretius Carus, O naturze rzeczy, przełożył, wstępem i komentarzem opatrzył G. Żurek, Warszawa 1994. 


\section{Paraklausithyron jako nośnik uczuciowości elegijnej (topika)}

O paraklausithyronie w rzymskiej elegii miłosnej ${ }^{25}$ napisano już wiele, choćby przy okazji analizy utworów poszczególnych elegików - ale raczej nie w języku polskim. Dla niniejszego wywodu istotne byłoby jednak szkicowe przynajmniej wskazanie, jak exclusus amator łączy się z innymi charakterystycznymi dla gatunku motywami, stając się nośnikiem typowo elegijnej uczuciowości i charakterystycznego obrazowania.

Miłość elegijna w łacińskiej odmianie (analogicznie - w obrębie ówczesnych relacji społecznych - w renesansowej, choć istniała tu pewna wariacyjność, jak typ amor coniugalis ${ }^{26}$ ) dotyczyła relacji między wolnym mężczyzną, zapewne reprezentantem klasy zubożałych ekwitów, nadto literatem, a kobietą z półświatka, podległą stręczycielowi niewolnicą zamieszkującą dom nierządu, bądź samodzielną „luksusową" heterą, byłą niewolnicą, która odzyskała wolność i prowadzi własny dom. Niekiedy dziewczyna była „zaślubiona” swojemu patronowi bądź stanowili oni parę wyzwoleńców, połączoną nieformalnym związkiem małżeńskim (nie przysługiwały im bowiem prawa rodzinne obywateli), w którym też nie przestrzegano zbyt rygorystycznie zasady wierności.

W każdej z opisanych sytuacji bohater elegii, poeta darzący ukochaną prawdziwą, najgłębszą miłością, czuł się w posiadaniu większych praw do niej, niż ów zły stręczyciel czy zdradzający ją, albo stary i zgrzybiały „mąż”. Ma tu więc miejsce zwykle amor furtivus - miłość kryjoma, kradziona, napotykająca mnóstwo przeszkód - co czyni ją też bardziej ponętną. Drzwi są zamknięte, a czuły kochanek musi pieśnią skłonić ku sobie panią, zmylić straże, przekupić stróża, ubłagać zawarte wrota ${ }^{27}$. Poeta ów jest jednak ubogi (pauper poeta) i gdy pieśń nie wystarczy, ustąpić

${ }_{25}$ Wypada podkreślić, że z gatunkiem elegii paraklausithyron związał się dopiero w Rzymie, elegii greckiej jest całkowicie obcy - zob. rozdziały: K. Bartol, Elegia okresu archaicznego oraz J. Danielewicz, Elegia w epoce hellenistycznej, w: Literatura Grecji Starożytnej, red. H. Podbielski, t. 1, Lublin 2005; Liryka grecka, t. 1: Jamb i elegia, oprac. K. Bartol, Warszawa 1999.

${ }_{26}$ Chodzi o zastosowanie konwencji elegijnej do opiewania miłości małżeńskiej - pierwszy taki zbiór zatytułowany De amore coniugali powstał pod piórem G. Pontana - zob. G. Urban-Godziek, Elegia renesansowa. Przemiany gatunku w Polsce i w Europie, Kraków 2005, s. 144-159.

${ }_{27}$ Tu szereg postaci: stręczyciel lub rajfurka (leno, lena), mąż (coniux), pilnująca sługa (custos) czy przyzwoitka, u Owidiusza również odźwierny (ianitor, elegia I 6) - niewolnik, kastrat (więc nierozumiejący sytuacji udręczonego żądzą kochanka), przykuty łańcuchem do odrzwi (elegia II 3). 
musi bogatszemu (dives amator): „heu canimus frustra nec verbis victa patescit/ ianua sed plena est percutienda manu” („Ach, na próżno śpiewam, słowa nie zdołają zmusić drzwi, by się otwarły, lecz trzeba w nie uderzać pełną ręką", Tib. I 5, 67-69). Tej bądź co bądź zasady płatnej miłości szalejący z rozpaczy, targany zazdrością kochanek jednak nie uznaje. Dziewczyna, gdy ulegnie innemu, oskarżana jest o zdradę, niekiedy darzona wyrzutami z gwałtownością, do jakiej ten rodzaj miłości wcale nie upoważniał.

Wspomniany aspekt wydaje się istotny w kontekście ewolucji miłości elegijnej, zmierzającej ku uczuciu romantycznemu, zakładającemu pełne wzajemne oddanie obojga - aż po granicę śmierci. Wyprzedzając późniejsze rozważania, można nadmienić, że elegijny paraklausithyron renesansowy w swojej naukowej ścisłości i rzetelności historycznej niekiedy bardzo precyzyjnie oddaje charakter tego związku. Czasem jednak sytuacja kochanków jest dość niejasna - niekiedy trudno się zorientować, czy daną „opowieść” o miłości winno się umieścić w ramach obyczajowości chrześcijańskiej szesnastowiecznej Europy, czy obowiązuje tu wciąż konwencja klasyczna (do tych zagadnień jeszcze wrócimy). Elegie poetów, którzy w obrębie antycznej materii i języka stworzyli „nową jakość”, oddziałującą na dalsze losy liryki europejskiej, jak Giovanni Pontano czy Janus Secundus, i tę relację między kochankami traktują z nieco większą swobodą klasycysta Kochanowski będzie tu jednak precyzyjny. W jego elegii II 4 Wenera, inspiratorka podstępów miłosnych (furta venris), strofuje desperującego poetę za nadmierne żądania wobec dziewczyny, która wszak nie jest jego żoną:

Atqui non facibus succensis, non Hymenaeo

Deducente tuum contigit illa torum,

Sed furtim et tacitis obrepsit sola tenebris,

Quodque facit, nulla lege coacta facit ${ }^{28}$.

(Koch.El. II 4, 41-44)

A ta nie wśród płonących pochodni, nie przez Hymena

prowadzona, w twoje trafiła łoże,

${ }^{28}$ Najnowszą edycję książkową dzieł łacińskich Kochanowskiego stanowi tom: J. Kochanowski, Carmina Latina / Poezja łacińska, cz. 1, fototypia-transkrypcja, wydała i wstępem poprzedziła Z. Głombiowska, Gdańsk 2008. W artykule niniejszym jednak teksty łacińskie Kochanowskiego wraz z odpowiednimi przekładami powtarzającymi lekcję, a zwłaszcza wybory interpunkcyjne transkrypcji, przytaczam za powstałą pod moim kierunkiem edycją internetową (http://neolatina.bj.uj.edu.pl/) opartą na pierwodruku: I. Cochanovius, Elegiarum libri IV. Eiusdem Foricoenia sive Epigrammatum libellus, Cracovia 1584. 
lecz niepostrzeżenie, sama, skradała się w nocnej ciszy, i wszystko, co czyni, czyni nie pod przymusem ${ }^{29}$.

Gdzie indziej (w paraklausithyronie), żaląc się na sprzedajność dziewczyny, nie chce uznać „praw rynku”: „Quid? Quod nulla empto debetur gratia lecto, / Et mercede data liber amator abit” („Cóż z tego, że za płatną miłość nie należy się żadna wdzięczność/ i że po zapłacie kochanek idzie wolny w swoją stronę?”, elegia I 8, 33-34).

Również konstytutywny dla gatunku topos servitium amoris (służba, niewola miłosna) znajduje realizację $\mathrm{w}$ ramach paraklausithyronu. Kochanek wiernie czuwający na progu jako niewolnik miłości jest jakby przykuty do drzwi: „me retinent vinctum formosae vincla puellae, / et sedeo duras ianitor ante fores" („Mnie dziewczyna spętała swoimi okowy/ I jak odźwierny siedzę u jej drzwi surowych" ${ }^{\circ}$, Tib. I 1, 55-56). Topos ten rozwija Tibullus w elegii II 4:

Hic mihi seruitium video dominamque paratam: iam mihi, libertas illa paterna, vale.

servitium sed triste datur, teneorque catenis, et numquam misero vincla remittit Amor.

(Tib. II 4, 1-4)

Widzę, że przychodzi mi w niewolę iść do pani na to gotowej: żegnaj mi wolności dziedziczna!

Ale smutną mi dano niewolę, noszę kajdany, i nigdy mnie nieszczęsnemu więzów nie rozluźni Amor.

Jest to pieśń desperacji, bo na nic się zdają natchnione pieśni pod drzwiami, gdy tylko złoto może je otworzyć. Zrozpaczony poeta odpędza więc bezużyteczne muzy i wypowiada służbę u drzwi: „ne iaceam clausam flebilis ante domum” („żebym nie leżał we łzach przed domem”, w. 22), rzucając przekleństwa na chciwość dziewcząt i strasząc je nadchodzącą starością.

Z omawianym motywem złączony został również inny typowo elegijny, antyheroiczny - militia amoris (wojna miłosna, służba wojskowa miłości). Opór drzwi bowiem może wywołać (zwłaszcza u zamroczonego Bakchusem komastesa) postawy bardziej waleczne: „nunc levis est tractanda venus, dum frangere postes/

29 Elegie J. Kochanowskiego z I i II księgi cytuję w przekładach Grzegorza Franczaka, z III księgi zaś - Elwiry Buszewicz, zamieszczonych na wspomnianej powyżej stronie internetowej.

$3^{\circ}$ Przekład A. Świderkówny. 
non pudet et rixas inseruisse iuvat./ hic ego dux milesque bonus” („Dzisiaj czas jest Wenery, póki jeszcze można/ Zuchwale drzwi wyważać i sprzeczka nie zdrożna./ Tu ja wódz, żołnierz dobry" ${ }^{\mathrm{I}}$, Tib. I 1, 73-75).

\section{Paraklausithyron w poezji renesansowej}

Poezja renesansowa, która adaptowała liryczne wzorce rzymskie - poczynając od Katullusa i elegików, a następnie zapoczątkowując nowożytną lekturę liryki Horacego - przyswoiła sobie oczywiście także ten motyw, doskonale rozumiejąc jego znaczenie i rolę. Jako że nie ma jeszcze prac poświęconych zagadnieniu renesansowego paraklausithyronu, niniejsze rozważania będą miały charakter jedynie szkicowy, egzemplifikacyjny, by na tak zarysowanym tle pokazać dwujęzyczną realizację toposu w dorobku Kochanowskiego.

Włoska literatura drugiej połowy $\mathrm{XV}$ w. to z perspektywy Italii niewątpliwie okres dojrzałego humanizmu, mającego przynajmniej półwiekowy staż, poprzedzony ponadto dorobkiem średniowiecznych pisarzy-filologów (korona toskańska, prehumanizm padewski). Tę dojrzałość widać choćby w biegłości i swobodzie, z jaką poeci posługują się klasyczną materią i klasyczną formą. Niemniej jest to epoka, która wciąż ustala kanon lektur klasycznych, próbuje odtworzyć kształt tekstów dochowanych niekiedy w postaci bardzo okrojonej, popsutej, przybliżyć ich znaczenie, znaleźć sposoby otwarcia, rozszyfrowania szczątkowych przekazów tak odległej kultury. Jest to więc epoka swoistej archeologii filologicznej i radosnego eksperymentowania klasycznymi formami - co więcej, dokonywanego zwykle równolegle w dwóch językach: łacińskim i włoskim. Pisarze tacy jak Cristoforo Landino, Tito Vespasiano Strozzi, Angelo Poliziano, Jacopo Sannazaro parali się imitatio antiquorum w obrębie form i języka klasycznego, i jednocześnie poezją w volgare w sposób naturalny wpisywali się w ciąg rozwoju dwuwiekowej literatury rodzimej. Rzecz jasna, taka dwutorowość owocowała wzajemnym wpływem tych dwóch poetyk na siebie. O ile na przykład we Francji bujna tradycja literatury średniowiecznej stawała się w pewnym sensie przeszkodą w przyjęciu nowej, klasycyzującej (vide poeci Plejady, wiek później, zwalczający poprzedników za ich staroświeckość, nieklasyczność - np. konflikt Ronsard-Marot ${ }^{32}$ ), o tyle w Italii, gdzie renesans powstawał,

${ }^{\text {I }}$ Przekład A. Świderkówny.

${ }^{2}$ Zob. Ch.M. Scollen, The Birth of the Elegy in France 1500-1550, „Travaux d'humanisme et renaissance”, t. 45, Genève 1967, s. 153-156; G. Urban-Godziek, Elegia renesansowa..., s. 305-309. 
proces wzajemnego oddziaływania na siebie tych dwóch nurtów był znacznie bardziej płynny i bezkonfliktowy. Dlatego też niekiedy szesnastowieczny renesans zaalpejski, przyswajając eksportowane z Italii mody literackie, bywa bardziej klasycyzujący niż ten wzorcowy - piętnastowieczny włoski.

Trudno dziś określić, w jakiej mierze klasyczny motyw paraklausithyron zespolił się w Italii z formami rodzimymi. Naturalną kontynuacją komosu byłby bowiem gatunek serenady. Wiele przykładów, zwłaszcza siedemnastowiecznej literatury (również polskiej33), wskazuje, że poeci - wykształceni klasycznie przecież - tę modną formę poetycko-muzyczną łączyli z motywem znanym z lektur antycznych. Nie sposób obecnie stwierdzić, kiedy paraklausithyron złączył się z romańską, a właściwie włoską, serenadą rozpoczynającą karierę w okresie renesansu. Wydaje się (niestety nie udało mi się dotąd znaleźć ani w literaturze włoskiej, ani w innej szczegółowych badań poświęconych źródłom serenady literackiej), że tradycja ulicznych śpiewów pod drzwiami czy oknem dziewczyny trwa w Italii nieprzerwanie od czasów Plauta czy Lukrecjusza do naszych czasów. Opisywany szeroko w literaturze wieków XVII-XIX obyczaj nakazujący ubiegającemu się o rękę panny śpiewać przy dźwiękach lutni lub zamawiać kapelę muzykującą co wieczór pod oknem dziewczyny jest we Włoszech żywy i dziś.

Wbrew temu, co podają polskie (i nie tylko) słowniki terminów literackich 34 , niemożliwe do udowodnienia są prowansal-

33 Świetnym przykładem jest tu Serenada (Kanikuła 30) J.A. Morsztyna, wyraźnie operująca wątkami pochodzącymi z antycznego komosu: „Ja tylko nie śpię, jam tylko sam czuły. / Wszytkie te gwiazdy widzą me niewczasy, / Kiedy wieńcami zdobię twe zawiasy/ Albo-ć sen słodzę śpiewaczymi głosy,/ Albo skrzypkami, choć się boją rosy”. J.A. Morsztyn, Utwory zebrane, oprac. K. Kukulski, Warszawa 1971, s. 182, w. 8-12.

34 Przykładowo zob. T. Kostkiewiczowa, Serenada [hasło], w: Stownik terminów literackich, red. J. Sławiński, Wrocław 2000: „W poezji włoskiej pieśń liryczna o tematyce miłosnej wywodząca się od prowansalskiej sereny, wykonywana wieczorem pod domem ukochanej przy wtórze instrumentu muzycznego". Wystarczy skojarzenie tej definicji z hasłem Serena opracowanym przez S. Łukasika w „Zagadnieniach Rodzajów Literackich” (1960, t. 3, z. 2, s. 151), by dostrzec nieprzystawalność tych opisów: „Serena jest pieśnią wieczorną, która wyraża oczekiwanie nocy, obiecującej nowe rozkosze miłosne. Podczas gdy w albie kochankowie złorzeczą porannej zorzy, której zjawienie się zmusza ich do rozstania się, w serenie powodem rozpaczy kochanka jest dłużący się w nieskończoność dzień, który przeszkadza mu połączyć się z ukochaną. Serena Ad un fin aman fon datz Guiratua Riguier jest jedynym zachowanym przykładem tego rodzaju”. Z przejrzanych przeze mnie różnojęzycznych słowników najrzetelniejszy wydaje się Dictionnaire des termes littéraires (autorstwa H. van Gorp et al., Paris 2005), wspominający o serenadzie jako wieczornej albie, by zaraz przejść do późniejszej formy muzycznej (z przykładem z Mozarta), która rozwinie się w XVIII w. do małej opery; zjawisko to zostało też skojarzone $\mathrm{z}$ antycznym paraklausithyronem. Znamienne jest podanie tych trzech form 
skie źródła tego gatunku. Prawdopodobnie prowansalska (jeśli w ogóle) jest tu tylko nazwa. Zachowała się bowiem jedna serenada, i to ostatniego trubadura, Guirauta Riguera ${ }^{35}$, któremu też przypisuje się stworzenie tego gatuku. Poeta ów, utyskujący, że za późno się urodził (zaczął tworzyć już po krucjacie przeciw albigensom, czyli w chwili śmierci kultury oksytańskiej), jako utalentowany epigon pragnął starej formie nadać nową postać. Podjął więc gatunek alby - pieśni witającej z niechęcią poranne zorze, które zmuszają kochanków do rozstania się, by ich nocnej schadzki nie odkrył ktoś postronny - i utworzył jej wieczorną wersję. Bohaterem jego sereny jest niecierpliwy kochanek pieśnią przyzywający wieczór i noc, która ma dać mu radość tajnego spotkania $\mathrm{z}$ ukochaną. A zatem jest to forma zupełnie inna niż romantyczna pieśń będąca publicznym hołdem oddanym ukochanej. Wydaje się więc, że na powstanie renesansowej (a cieszącej się największym powodzeniem w muzyce barokowej i klasycznej) serenady złożył się obyczaj i piosenka „ludowa”, zwłaszcza z Neapolu, z klasyczną tradycją paraklausithyronu. Co do nazwy „serenada” - jeśli nie jest włoska, bo i takie są hipotezy dotyczące etymologii - może $\mathrm{w}$ istocie pochodzić $\mathrm{z}$ języka oksytańskiego. Literatura prowansalska bowiem, która bezpośrednio przyczyniła się do zainicjowania twórczości poetyckiej w językach Italii, jeszcze u progu renesansu była tam niezwykle modna. Nadanie rodzimemu gatunkowi nazwy prowansalskiej, pochodzącej z języka oksytańskiego, zapewne było nobilitujące. Podobnie jak miało to miejsce w przypadku powstałego na Sycylii sonetu (według niektórych badaczy, włoskie sonetto pochodzi od oksytańskiego son; zdrobniała forma nazywająca krótszy utwór to sonet).

Przejdźmy jednak do łacińskich, opartych na wzorcach klasycznych, renesansowych włoskich realizacji komosu. Analizowane przeze mnie teksty Basinia da Parma (1425-1457), Cristofora Landina (1424-1498), Giovanniego Pontana (1429-1503), Tita Vespasiana Strozzy (1425-1505) świadczą o doskonałej znajomości topiki gatunku elegii miłosnej, w tym komosu. Równocześnie można dostrzec dużą swobodę w operowaniu antycznymi motywami, $\mathrm{w}$ zestawianiu ich $\mathrm{z}$ innymi, niekoniecznie elegijnymi, oraz ogólną tendencję do nadawania swoistego kolorytu włoskiej poezji erotycznej i rodzimej obyczajowości. Paraklausithyra nieelegijne tego okresu są jeszcze bardziej swobodne,

gatunku bez płynnego powiązania ich ze sobą, na co chyba jeszcze nie pozwala obecny stan wiedzy.

35 Polski przekład - zob. Brewiarz miłości. Antologia liryki staroprowansalskiej, przeł., oprac. Z. Romanowiczowa, Wrocław 1963, s. 119-121. 
cechuje je większa różnorodność albo nawet mieszanie wzorców stylistycznych czy inkrustowanie katullańskich epigramatów wstawkami elegijnymi (np. Landino Xand. I 26 Ad Ginevram). Na tym tle - wyprzedźmy rozważania - utwory komastyczne Kochanowskiego wydają się bardziej klasyczne, bliższe antycznemu modelowi elegii, choć niewątpliwie Polak doskonale znał i włoskie rozwiązania sprzed wieku.

By pokazać sposoby renesansowego przystosowywania motywu, weźmy jeden z ciekawszych tekstów, dobrze wpisujących się $\mathrm{w}$ tradycję rzymską: Carmen nocturnum ad fores puellae ${ }^{36}$ $\mathrm{z}$ pierwszego elegijnego tomu Pontana, Parthenopeus sive Amores (elegia I 3). Utwór ten jest przykładem dążności do stworzenia nowego paraklausithyronu na podstawie wielorakich wzorców rzymskich, z widocznym pragnieniem emulacji z ich autorami. Pomysł na tę pieśń polega między innymi na multiplikacji adresatów nocnej pieśni pod drzwiami. Jak już wspomniano, cechą rzymskiego komosu jest personifikacja drzwi, które stają się adresatem tęsknych zawodzeń lub obelg, albo też osobą mówiącą (Plaut.Curc. 16, 88-91; Cat. 67; Prop. I 16). Zwykle jednak topos ten występował samodzielnie - pierwszy raz w elegii I $2 \mathrm{Ti}$ bullusa widzimy podwójnego adresata: najpierw drzwi (mające naczelną, pierwszą pozycję w rzymskim komosie), a następnie ukrytą za nimi dziewczynę. A wszystko to po wstępie podkreślającym wpływ bakchusowego trunku37.

Pontano zdaje się podążać za rozwiązaniami Tibulla, rozwijając je jeszcze - również korzystając z tekstu Curculia, co zresztą nie jest dziwne, gdyż Plaut był jednym z najważniejszych autorów, od których humaniści z kręgu neapolitańskiego zaczynali, wprowadzając jego język i obrazowanie do liryki erotycznej. Mimo tych i innych jeszcze wzorów (zapewne też Prop. I 3, 25ff) i mimo rzucającej się w oczy klasyczności wykorzystanych mo-

${ }^{6}$ Utwór ten przedstawiam szerzej również dlatego, że pojawia się w literaturze poświęconej Kochanowskiemu jako możliwe źródło jego pomysłów (zob. M. Hartleb, Jan Kochanowski $i$ włoskie Cinquecento, w: Pamiętnik Zjazdu Naukowego im. Jana Kochanowskiego w Krakowie 8 i 9 czerwca 1930, Kraków 1931, s. 244). Za nim chyba, jako typowy przykład paraklausithyronu renesansowego podaje się ten utwór jako kontekst elegii Kochanowskiego. Mimo niewątpliwie słusznej intuicji badacza o oddziaływaniu Pontana na mistrza z Czarnolasu, nie widać, by akurat ten utwór był bezpośrednią inspiracją paraklausithyrów Kochanowskiego.

37 „Adde merum vinoque novos compesce dolores, / occupet ut fessi lumina victa sopor; / neu quisquam multo percussum tempora baccho/ excitet, infelix dum requiescit amor” („Daj jeszcze mocnego wina, niech wino złagodzi nowe cierpienia; aby sen wziął $\mathrm{w}$ posiadanie zmęczone oczy pokonanego, niech nikt nie budzi, gdy wiele Bakcha przelano i gdy nieszczęśliwa miłość może odpocząć”, Tib. I 2, 1-4). 
tywów utwór ten nosi wyraźne piętno indywidualności oraz stylu Pontana, wpisuje się też w całość zbioru, z ulubionymi motywami świetlnymi, szeroko opracowanym tematem snu etc.

Tekst nocnej pieśni rozpoczyna się od sprecyzowania jej źródła - okrutne oczy dziewczyny zauroczyły zakochanego, przesłaniając mu wszystkie inne piękności ${ }^{8}$. I do niej, do Fanii, kieruje on pierwsze wezwania. Tu znowu pojawia się wariacja na temat elegijnego toposu dura puella - twardej, nieustępliwej dziewczyny. W myśl zasad rządzących pieśnią komasty (i co tu dużo mówić, spod lupanaru) dobra, łaskawa, chętna, uprzejma (benigna) dziewczyna to ta, która łatwo otwiera drzwi. Ta, która robi trudności, stawia przeszkody, jest zła, twarda (dura) i trudna (difficilis - Kochanowski tłumaczył: „nieużyta białogłowo”, Pieśni I 21, 8), zuchwała (proterva)39. Fania nie otwiera drzwi, a to jest objawem pychy, zatwardziałości serca i złych obyczajów (por. Koch.Pieśni I 15-16: „Gładkość wprawdzie sługi daje,/ Ale dzierżą obyczaje" $\left.{ }^{40}\right)$. Tym paradoksem swoistej elegijnej etyki à rebours ${ }^{\mathrm{I}}$ Pontano chętnie żongluje:

Nam, quamvis molli semper sis dedita amori,

Nulla proterva magis, nulla benigna minus;

Cum tibi sint placidi mores, sint mitia corda,

Nulla benigna minus, difficilisque magis.

Nam quid dura tuum sic me contemnis amantem,

Neglectumque tuas despicis ante fores?

(Pont.Parth. I 3, 8-12)

$3^{8}$ „Sic mihi crudeles isti placentur ocelli,/ Qui me luminibus surripuere suis, / Ut nulla e cunctis aeque formosa puella est, / Nec quae sit misero tantum adamata mihi” („Tak mi się podobają te okrutne oczy, które mnie ograbiły swoim spojrzeniem, że żadnej z dziewczą - równie ładnej - tak bym nie kochał nieszczęsny”, Pont.Parth. I 3, 1-4). Tekst oryginalny podaję za edycją: J.J. Pontano, Carmina, ecloge, elegie, liriche, red. J. Oeschger, Bari 1948.

39 Nie należy też zapominać, że w starożytności odrzucenie miłości jest winą - gr. adikia, którą pomścić muszą zarówno bogowie, jak i ludzie.

$4^{\circ}$ Por. z uwagą Z. Głombiowskiej odnoszącej się do tego fragmentu: „kochanka o dobrych obyczajach to taka, która nie jest harda, która nie pozostaje głucha na prośby wielbiciela” (Z. Głombiowska, Inspiracje elegijne w I ks. „Pieśni” Jana Kochanowskiego, „Meander” 1978, t. 33, cz. 1, nr 3, s. 148-158; cz. 2, nr 4, s. 211-223; cytowany fragment - s. 216). Utwory polskie Kochanowskiego przytaczam za edycją: J. Kochanowski, Dzieła wszystkie. Pieśni, oprac. M.R. Mayenowa, K. Wilczewska, przy udziale B. Otwinowskiej oraz M. Cytowskiej, Wrocław 1991 (Wydanie Sejmowe, t. 4). W cytatach pomijam jednak znaki diakrytyczne oznaczające pochylenie samogłosek.

${ }^{\text {I }} \mathrm{Na}$ temat odwróconej moralności zdrady, zakazanej tajemnej miłości, najpełniej wyłożonej w Tib. I 2 - zob. F. Copley, op.cit., s. 96-99. 
Bowiem, chociażbyś zawsze była oddana czułej miłości, żadna [nie będzie] bardziej zuchwała, żadna mniej uprzejma;

gdybyś ty była uprzejma, miała miękkie serce, żadna [nie byłaby] mniej uprzejma i trudniejsza.

Czemu bowiem, nieczuła, mną, twym kochanym, tak gardzisz, i lekceważysz opuszczonego przed twoimi drzwiami?

Choć, w przeciwieństwie do cytowanej elegii Tibullusa, nie ma tu mowy o upojeniu alkoholowym nadawcy nocnego komunikatu lirycznego, to całość długiego wywodu prowadzona jest z konsekwencją i z logiką pijanego. Gdy pani nie odpowiada, zwraca się do jej służącej, która nieraz, najwyraźniej przezeń nagradzana, ułatwiała schadzkę zakochanym, tak by nie widziała matka (!) dziewczyny (to nowość wobec klasyki - chyba że byłaby to mamma - włoska odpowiedniczka antycznej lena). Przy czym samo wspomnienie, że służąca śpi opodal pani, wywołuje cierpienie nieco zamroczonego kochanka na myśl o jej słodkim łożu. Ale też znalazł się nowy winowajca - sen, który pogrążył obie, tak że nie słyszą wołania udręczonego: „Sed tibi quid feci, crudelis somne? Quid, inquam, / Dure, meas frangis, somnule, delitias?” („Lecz tobie cóż uczyniłem, okrutny śnie? Czemu, pytam, nieczuły, moje radości niszczysz, senku?", w. 34-35). Tu następuje długa przemowa do bóstwa Snu - być może zazdrosnego o radość kochanków - podparta dobrym przykładem Nocy, która wspiera ukrywaną miłość (por. w tym samym zbiorze Hymnus ad noctem, Pont.Parth. I 7, sławiący dobrodziejstwa tej przyjaciółki kochających). Gdy w swej logice pijanego bohater chce już uśpić sen, rozpoczyna następną prekację (tu parafraza Plauta) - tym razem do rygli zamykajacych drzwi, które mają być uczczone ofiarą błagalnika. Na nic jednak prośby i modlitwy - znużony klnie okrucieństwo rygli, odrzwi i bramy. Czując już zmęczenie zbyt wielkie, by o własnych siłach dotrzeć do domu, ostatnie słowa kieruje do drzwi, zrzucając na nie odpowiedzialność za swoją śmierć. Zatem konsekwentnie, próg stanie się jego kamieniem grobowym ${ }^{42}$.

Zatrzymajmy się chwilę przy motywie śmierci na progu. Samobójstwo, które u rzymskich elegików pojawia się w gwałtownych, desperackich wyznaniach Propercjusza, raczej nie bywa skojarzone $\mathrm{z}$ paraklausithyronem. W jednym tylko przypadku (Prop. II 14, 31-32) pojawia się sugestia śmierci u drzwi, choć

${ }^{42}$ Motyw pieśni u progu śpiewanej dla twardej jak kamień dziewczyny stał się też źródłem konceptu budującego wiersz Queritur ante limen puellae (Pont.Parth. II 16). Wobec jej oporu kochanek marzy, by sam mógł stać się kamiennym progiem, po którym stąpałaby Fania. 
mamy tu wyraz vestibulum - przedsionek, a nie jedno z komastycznych słów kluczy oznaczających drzwi lub próg. Samobójcza śmierć $\mathrm{w}$ ścisłym związku $\mathrm{z}$ lamentem u drzwi pojawia się jedynie w epickiej opowieści Owidiusza z Metamorfoz (XIV 698-758). Opowiada on o młodym Ifisie, który zapłonął miłością do szlachetnie urodzonej Anaksarety. Jego nieustanne hołdy przy drzwiach domu, błagania i zaklęcia były bezwzględnie odrzucane przez piękną, dumną dziewczynę. W końcu zdesperowany zamiast wieńca kwietnego powiesił sam siebie na odrzwiach, przy których tylekroć płakał. Drgające nogi nieszczęśnika uderzały w drzwi, wieszcząc ostatni hołd Ifisa, a patrząca z balkonu na jego pogrzeb Anaksareta skamieniała.

To jednak fragment niekanoniczny, nieelegijny i anachroniczny 43 - w starożytności starający się o rękę wybranki (co miało miejsce $\mathrm{w}$ przypadku Ifisa) nigdy nie dobijałby się do jej drzwi, gdyż to zniesławiało kobietę. Co jednak charakterystyczne i warte podkreślenia, ta tragiczna romansowa opowieść wzorowana jest na bukolice, a ściślej idylli 23 z Corpus Theocriteum, w której wzgardzony chłopiec wiesza się na drzwiach w miejsce wieńca. W poezji pastoralnej bowiem od jej literackich początków, czyli pieśni Teokryta o Dafnisie, w idyllicznej krainie obecna jest śmierć z miłości. Co istotne, powyższy motyw z $\mathbf{M e}-$ tamorfoz zawędrował znowu do bukoliki ${ }^{4} 4$, ale już oczyszczony z elementów komastycznych, przenosząc sytuację w świat pasterzy i przestrzeń lasu. Ta bukolika, nosząca zresztą cechy elegii miłosnej ${ }^{45}$, to ekloga III Pseudo-Calpurniusa Siculusa (druga połowa III w.). Wspominam o tym, ponieważ między tymi gatunkami, bukoliką i elegią, w ich bardzo długiej historii ciągle zachodziła wymiana motywów; nastrój elegijny kształtował się na podstawie pastoralnego, co prowadziło ten przecież frywolny rzymski gatunek do sublimacji uczuć, nakierowania ich w stronę „sentymentalną”. W XVII w. natomiast poezja pastoralna przejmuje wiele cech elegii, niejako zastępując ten gatunek, znów przeobrażony - tym razem w kierunku lamentu żałobnego.

43 F. Copley, op.cit., s. 137. Badacz ten traktuje całą twórczość elegijną Owidiusza jako wtórną, realizowaną niejako po śmierci czy wyczerpaniu się gatunku.

44 Ibidem, s. 140.

45 T.K. Hubbord podkreśla elegijny charakter tej eklogi - wyraźne są tu niebukoliczne motywy miłości elegijnej, jak zazdrość, „przemoc domowa”, skrucha, list miłosny, zastraszenie samobójstwem, epitafium umierającego kochanka, tudzież terminologia, jak choćby domina - zob. T.K. Hubbord, The Pipes of Pan. Intertextuality and Literary Filiation In the Pastoral Tradition from Theocritus to Milton, Ann Arbor 1998, s. 152-153. 
Świetnym przykładem wzajemnego „transferu” motywów między oboma gatunkami jest ekloga II Glyce $e^{46}$ współczesnego Kochanowskiemu Pietro Angeliego da Barga (1517-1596). Jest to bukolika oparta między innymi na lamencie Lycidasa z eklogi Calpurniusa - prócz tych samych imion bohaterów powtarza schemat przedśmiertnego lamentu kochanka, który na koniec formułuje własne epitafium i wycina je na korze dębu. Utwór ten jednak otwiera klasyczny, elegijny paraklausithyron z wszelkimi niezbędnymi cechami - inaczej niż $\mathrm{w}$ innych bukolicznych komosach, nie brak w nim nawet progu, choć rzecz dzieje się w lesie. Główną część lamentu wypełnia zapowiedź samobójczej śmierci zawiedzionego Lycidasa.

Elegia renesansowa nie jest pozbawiona wizji samobójczych, czego dowody można odnaleźć na przykład u Jana Kochanowskiego czy Conrada Celtisa (1459-1508), który pragnie uwolnić się od dręczącej miłości do Hasiliny i zostać pogrzebany w Tatrach (Amores I). W paraklausithyrach zazwyczaj jednak, zważywszy pewnie na zamroczenie kochanka, zastraszanie samobójstwem traktowane jest raczej żartobliwie. Zdarzają się też bezpośrednie nawiązania do Metamorfoz, jak w elegii Janusa Secundusa (I 5, 9-15).

Przedstawiając renesansowy paraklausithyron, warto jeszcze wskazać inny charakterystyczny przykład powstałego w Italii humanistycznego utworu, który wykazuje wiele związków z poetyką współczesnej liryki. Stanowić go może elegia Landina ze zbioru Xandra, Ad Xandram II 7. Rozpoczyna ją przedstawienie tematu - oto już od czterech lat zła miłość (male amor) więzi nieszczęsnego kochanka (misero mibi). To miłość elegijna, niezaspokojona, bolesna - przekraczająca miarę ludzką i boską: nie dorównają jej odczucia Wenery patrzącej w oblicze Adonisa ani popychająca do szaleństwa miłość Medei do Jazona. Choć ogień namiętności przenikał obie kobiety do szpiku (typowe antyczne określenie), nie może on być zestawiany z płomieniami ogarniającymi zamkniętego za drzwiami kochanka Xandry (ów żar namiętności zderzony zaraz zostanie z przenikliwym chłodem nocy, który musiał wielokrotnie cierpieć amator exclusus ${ }^{47}-$ takie

46 P.A. Bargle, Poemata omnia, t. 1, Romae 1585, s. 226-229.

47 Zob. opis sytuacji komastycznej: „Ah quotiens totas gelido sub sidere noctes / Egimus ante tuas, dura puella, fores, / Tristiaque in iunctos torquens convicia postes/ Lugebam misero limina clausa mihi!/ Heu, modo vernali suspendi flore coronas, / Intexens rubris lilia cana rosis” („Och, ileż to razy pod zimnymi gwiazdami, okrutna dziewczyno, całe noce spędzałem przed twoimi drzwiami, i cierpiąc u zawartych wrót pełne wrogości złorzeczenia, płakałem przed wejściem - na me nieszczęście zamkniętym! Ech, jeszcze wieńce wieszałem $\mathrm{z}$ wiosennych kwiatów, $\mathrm{z}$ róż czerwonych splecionych $\mathrm{z}$ białymi 
kontrastowe zestawienie nosi znamiona stylu petrarkistowskiego, w którym Landino tworzył po włosku $\left.{ }^{48}\right)$. To bezsenność objaw choroby miłosnej (morbus amoris) - nie pozwala mu spocząć ${ }^{49}$. Lecz mimo nocnych straży, wieńców na drzwiach witych z kwiatów wiosny: śnieżnych lilii i purpurowych róż $5^{\circ}$, cichych żalów i wyznań szeptanych przez szparę, ona pozostawała głucha na pieśni ${ }^{1}$. Wyznanie tych długich nieszczęść kończy renuntiatio amoris - deklaracja zrzucenia pełnej boleści niewoli miłosnej ${ }^{22}$, wymówienie służby u srogiej dziewczyny (por. Koch.Pieśni I 23, 3-4: „Ale to nade wszystko za raz odżałować, / A niewdzięcznemu panu tudzież podziękować”).

Jedyna satysfakcja, jaką erotyka antyczna, a zwłaszcza tradycja elegijna, zostawia zawiedzionemu kochankowi po odwołaniu miłości, to nadzieja, że albo dziewczyna będzie gorzko żałować tej straty, albo zostanie ukarana za swą pychę i nieczułość - na ziemi (choćby przykrą starością i lekceważeniem ze strony młodych amantów) i po śmierci (kara w Hadesie). Jest też wariant sentymentalny w duchu bukolicznym i Tibullańskim: gdy on umrze ze zgryzoty, wtedy dziewczyna przynajmniej zapłacze nad grobem. Landino wybiera rozwiązanie pierwsze, podając przykład nieszczęść, jakie sprowadzają harde kobiety, wystawiające na zbyt ciężkie próby swych ukochanych. Temu służy rozbudowane mitologiczne exemplum - Oenone, która przeliczyła się w swych nadziejach, myśląc, że Parys na zawsze pozostanie jej wierny. Za to przyszło jej płacić gorzkimi łzami wylewanymi nad sobą samą i spaloną Troją. Wiersz kończy się jednak nadzieją na opamię-

liliami”, w. 18-23). Podaję za bazą internetową Poeti d'Italia in lingua latina (http://www.mqdq.it/mqdq/poetiditalia, dostęp: 13 września 2011) przedrukowującą wydanie: A. Perosa, Christophori Landini Carmina omnia, Florentiae 1939.

$4^{8} \mathrm{O}$ związkach elegii renesansowej z petrarkizmem - zob. G. Urban-Godziek, Elegia renesansowa..., s. 93-95 oraz - w kontekście zbioru elegijnego Secundusa - s. 123-142.

49 „Me miserum! Non ora cibus, non lumina somnus/ Intrat et in toto corpore nulla quies” („O, jakżem nieszczęsny! Żaden pokarm nie pokrzepi mych ust, ni sen oczu, ani spoczynek ciała”, w. 14-15).

5o Widać tu nową funkcję wieńca - to już nie jest pozostawiony na drzwiach przez pijanego komastę „świadek mego niewyspania” (Koch.Pieśni I 21, 48), ale hołd kwietny dla dziewczyny.

${ }^{\text {II }}$ „Et modo per rimam tenui sub voce querelas/ Immisi et tenui verba notata sono. / At cecini surdae; nam cum tibi carmina dicto, / Protinus aspideis auribus ista caves” ( „I tak przez szparę cichym głosem żale sączyłem i cichą mową wypowiedziane słowa. Lecz śpiewałem głuchej - bo ilekroć ci pieśni próbuję powtarzać, ty natychmiast dostępu im bronisz żmijowymi uszami”, w. 23-27).

52 "Tempus adest requiem tanto praestare labori, / Nostraque disrupto solvere colla iugo” („Już czas, by pozwolić na odpoczynek po takiej pracy i uwolnić mą szyję z pękniętego jarzma”, w. 29-30). 
tanie Xandry: jeśli wyzbędzie się pychy i nakłoni ucho do próśb kochanka, życie do niego powróci.

\section{Paraklausithyron w renesanowej teorii poezji}

Świadectwem roli, jaką w obrębie gatunku elegii przypisywano paraklausithyronowi, niech będzie też wywód teoretyczny zapisany w jednej z najpopularniejszych poetyk renesansu, Poetices libri septem Juliusza Cezara Scaligera (1484-1558). W rozdziale 125 księgi III (edycja pośmiertna z 1581 r.) modyfikuje on swoje wcześniejsze ustalenia (z wydania z 1561 r.), jakoby materię elegijną stanowiły pierwotnie żałobne lamentacje:

Quid est elegia, suo loco dictum est. Eius materiam primum aiunt fuisse lugubre, quo et diximus in primo. Nobis non placet, sed ab amantium commiserationibus dictam puto. Vox est tragica eleleu, qua ad amicarum fores usos fuisse priscos arbitror. Voti deinde compotes, quasi eiusmodi carmini gratiam referent, etami secundiorem illam fortunam celebrarunt. Est autem carmen aptum conquestionibus 53 .

Czym jest elegia, zostało powiedziane w swoim miejscu. Mówią, że początkowo jej tematyka była żałobna, co też powiedziałem uprzednio. To mnie teraz nie zadowala, lecz sądzę, że jej nazwa powstała od lamentów kochanków. Jest to, jak mniemam, tragiczne zawołanie eleleu, którego starożytni używali przed drzwiami kochanek. Następnie, gdy ich życzenia się spełniły - jakby w ten sposób składali dziękczynienie pieśni, albowiem ów pomyślniejszy los sławili. Jest to więc pieśń odpowiednia do lamentów.

Taka definicja elegii powstała na podstawie ówczesnej interpretacji fragmentu Listu do Pizonów Horacego:

Versibus impariter iunctis querimonia primum,

Post etiam inclusa est voti sententia compos;

Quis tamen exiguos elegos emiserit auctor,

Grammatici certant et adhuc sub iudice lis est.

(Hor. Ars Poet. $75-78$ )

53 J.C. Scaliger, Poetices libri septem. Sieben Bücher über die Dichtkunst, t. 1, ks. 1-2, red., przeł., komentarz, wstęp L. Deitz, Stuttgart-Bad Constatt 1994, s. 200. 
W wersy nierówne ujęta została najpierw skarga, potem także słowa spełnionych życzeń;

jaki jednak autor wydał krótkie elegie,

gramatycy się spierają i wciąż jest to kwestia nierozstrzygnięta.

Dziś uważa się, że wypowiedź Horacego dotyczy nie tyle elegii, co dystychu elegijnego i wyrażonych w nim epitafiów (querimonia - „żale”) oraz epigramów wotywnych (voti sententia compos - „słowa spełnionych życzeń”). O samej elegii mówi poeta jedynie, że jest mniej istotna od wymienionego wcześniej eposu i że jej pochodzenie jest niewiadome. W średniowieczu tekst ten zdawał się potwierdzać tradycyjne (ukształtowane przez aleksandryjskich etymologów w III w. p.n.e) związki początków elegii z żałobnym lamentem. Konfrontacja z praktyką literacką, dającą głównie przykłady zastosowania gatunku do opiewania miłosnych uczuć, doprowadziła jednak do próby pogodzenia tej sprzeczności w formule querimonia amantium („,̇ale kochanków") i zgadzała się ze sposobem miłowania przedstawionym w elegii rzymskiej i jej melancholijnym nastrojem ${ }^{54}$. Elegijne cykle renesansowe przedstawiają już wyrazistą i często podaną chronologicznie (w przeciwieństwie do zbiorów antycznych) historię miłosną w dwóch czy trzech odsłonach: starania o dziewczynę, krótki czas szczęścia (zawsze podszytego niepokojem) i bolesny długotrwały zawód spowodowany niewiernością kochanki, a w końcu zerwanie pozostawiające ból, żal, pragnienie zemsty lub samobójstwa we wciąż miłującym kochanku-poecie.

Według Walthera Ludwiga ${ }^{55}$ przytoczona formuła Scaligera, oddająca współczesną świadomość genologiczną poetów ${ }^{56}$, odnosi się do owej historii miłosnej przedstawianej w cyklach elegijnych. Elegia wyrażać więc miała stany emocjonalne kochanka: najpierw udręczonego niezaspokojoną namiętnością (Hor. querimonia, vota - „pragnienia”, Scalig. amantium commiserationibus), a później radującego się spełnieniem (Hor. voti sententia compos, Scalig. Voti deinde compotes) i tego dotyczy przedostatnie z przytoczonych zdań Scaligera. Co dla nas interesujące, za pierwotną formę elegii, od której miałaby ona wziąć nazwę, teoretyk uznał paraklausithyron. Taka etymologia mogła być po-

54 Szerzej o teorii gatunku od antyku do wieku XVIII - zob. G. Urban-Godziek, Elegia renesansowa..., s. 79-106; J.C. Scaliger, op.cit., s. 91-96.

55 W. Ludwig, Petrus Lotichius Secundus and the Roman Elegists: Prolegomena to a Study of Neo-Latin Elegy, w: Classical Influences on European Culture A.D. 1500-1700, red. R.R. Bolgar, Cambridge 1976, s. 175-177.

${ }^{5} \mathrm{~W}$. Ludwig przedstawia świadectwa leksykalne takiej interpretacji fragmentu z Arspoetica w zbiorach elegii J. Secundusa i P. Lotichiusa. 
dyktowana wyłącznie powszechną obecnością omawianego motywu w elegii. Najwyraźniej dla Scaligera ta forma nieodłącznie była związana z gatunkiem.

\section{Paraklausithyra łacińskie Jana Kochanowskiego}

Jan Kochanowski (1530-1584), zgodnie z konwencją elegijną, często odwoływał się do motywów komastycznych. Przy bliższej analizie prowadzonej w kontekście wzorców rzymskich oraz renesansowych i późniejszych właściwie wszystkie te utwory okazują się pełnymi paraklausithyrami - pieśniami śpiewanymi u zamkniętych wrót domu dziewczyny. Zaliczyć do nich można łacińskie elegie z księgi pierwszej (8, 12 i 14), z księgi drugiej (5 i 9), jak też elegię 1 z księgi trzeciej, odę 7 Ad Lycen, jak również trzy polskie pieśni (21, 23 i 25$)$ z ksiąg pierwszych (wątek komastyczny podejmuje też fraszka III 26 O Necie, oparta na epigramie z Antologii Palatyńskiej). Co charakterystyczne, z tych dziesięciu realizacji tylko wspomniana oda mieści się we wzorcu horacjańskim (ma jednak cechy bardziej epigramatyczne), podczas gdy reszta (pomijam fraszkę) należy do wzorca elegijnego.

Wypada jeszcze zwrócić uwagę na fakt, że paraklausithyra pisał Kochanowski jako dojrzały poeta - w wersji rękopiśmiennej Elegiarum libri duo (odpis z ok. 1560-1562 r.) ślady komosu są nader nikłe (zaznaczone jednym słowem fora w elegii II 7, 26 z Sylwy Osmólskiego - prototyp elegii II 5; w elegii II 10, 26 rozwiniętej w druku jako II 9). Prawdopodobnie dopiero później, z pewnością już w Polsce, gdzie w przeciwieństwie do Italii nie zwykło się śpiewać pod oknem ${ }^{57}$, docenił Kochanowski walory tego motywu i postanowił opracować go w najróżniejszych wersjach i obu językach.

W Elegiarum libri quattuor (wyd. w 1584 r.) Kochanowskiego jest zachowany wspomniany wyżej, charakterystyczny dla renesansu schemat historii miłosnej. Księga pierwsza „notuje” próby zdobycia dziewczyny i chwile wspólnego szczęścia - oczywiście, zgodnie z konwencją elegii, pełnego niepokoju i obaw o jej wierność. Księga druga jest historiąumierania miłości i rozpaczliwych prób odnowienia jej w sercu ukochanej, a potem wyzwolenia się $\mathrm{z}$ tego nieszczęsnego uczucia (księgę kończy symboliczne, doko-

57 Zob. Ł. Górnicki, Dworzanin polski, oprac. R. Pollak, Wrocław 1954, s. 203-204. Owa włoska moda w XVII w. rozpowszechniła się i w Polsce - zob. R. Grześkowiak, Okno Cyceryny - wymiary i głębia, w: Amor vincit omnia. Erotyzm w literaturze staropolskiej, red. R. Krzywy, Warszawa 2008, s. 18-29. 
nane we śnie samobójstwo) $5^{8}$. Trzecia księga natomiast otwiera, być może wzorowaną na modelu amor coniugalis ${ }^{5}$, historię nowej miłości, która ma znamiona spełnionych marzeń Tibullusa. I we wszystkich tych księgach znajdujemy paraklausithyron w trzeciej księdze również, lecz w formie renuntiatio amoris:

Rursus ad arma redis pharetrati mater Amoris,

Nulla tibi mecum pax diuturna placet;

Vix bene convaluit primo de vulnere pectus,

En iterum saevus cor mihi fixit Amor.

Parce, precor, primae ludum revocare iuventae,

Insanisse semel sit, Cytherea, satis:

Non ego dum lucem cristatus provocet ales,

Aptus ad occlusas iam vigilare fores,

Calcibus aut crebris inimicos tundere postes,

Et nunc blandicias, nunc adhibere minas.

Haec fieri potuere olim, maturior aetas

His alios mores postulat et studia.

(Koch.El. III 1, 1-12)

Znów za broń chwytasz, o matko Amora,

Nie chcesz mieć ze mną długiego pokoju!

Ledwo się z pierwszej wyleczyłem rany,

Już srogi Amor w me serce ugodził.

Odpuść, nie wzniecaj młodzieńczych igraszek,

$5^{8}$ Zob. G. Urban-Godziek, De consolatione somni - figura Pocieszycielki. Jan Kochanowski w nurcie tacińskiej literatury europejskiej (Boecjusz, F. Petrarca, G. Pontano, J. Secundus), w: Twórczość Jana Kochanowskiego w kontekście nowotacińskiej literatury europejskiej i polskiej, red. G. Urban-Godziek, Kraków 2010, s. 18-22 (edycja internetowa: http://neolatina.bj.uj.edu.pl/main/reports. html).

59 Dziś mniej oczywiste wydają mi się wcześniejsze moje ustalenia na ten temat (G. Urban-Godziek, Elegia renesansowa..., s. 186-192), a to między innymi ze względu na imię bohaterki III księgi, Pasiphile, pochodzące z fragmentu o sławnych kurtyzanach Deipnosophistae (wyd. 1514) Athenajosa. Również wykazywany w niniejszym artykule związek klasycznej elegii (Kochanowski niewątpliwie stara się zachować wzorzec klasyczny) z lupanarem podważałby te sugestie, które - oparte na analizie porównawczej ze strukturą De amore coniugali Pontana - zdawały się potwierdzać tradycyjne odczytywanie Pasiphile jako Doroty Podlodowskiej. Konstruując elegijny zbiór o miłości małżeńskiej, Pontano jednak wyraźnie unika wszelkich skojarzeń z muzą frywolną. Nie ma tu też paraklausithyronu (nawet w utworze wstępnym, mówiącym o staraniu się o przyszłą żonę). Jak wspomniano, już w starożytności śpiewanie pod drzwiami kobiety cieszącej się szacunkiem zniesławiało ją. W elegiach III księgi Kochanowskiego zupełnie nie widać takiej jak u Pontana tendencji puryfikacyjnej. Wizje szczęścia rodzinnego, na których badacze, jak choćby S. Windakiewicz, opierali swoje sugestie, mają łatwo rozpoznawalne źródło w elegiach Tibullusa. 
Niech ci wystarczy, że raz oszalałem.

Już nie te lata, by gdy kur zapieje,

Czuwać przy wrotach zamkniętych na głucho,

W drzwi nieprzyjazne kopniakami walić,

To się przymilać, to znów groźby rzucać.

Dawniej - nie mówię... ale wiek dojrzały

Raczej inaczej każe się prowadzić ${ }^{60}$.

Tego typu próby wyrzeczenia się miłości (wbrew woli i przemocy Wenery i Kupidyna), gdy odchodzi szalona młodość i, według zgodnej opinii starożytnych, nie wypada już tracić głowy dla dziewczyny (szalejący z miłości starcy i staruchy są częstym motywem satyr antycznych), znamy z licznych realizacji Horacego, czy z elegii I 1 Propercjusza. U Kochanowskiego nie jest to całkowite wyrzeczenie się miłości, ale raczej zwrot ku jej spokojniejszym, stosownym dla dojrzałego wieku formom (por.w. $29 \mathrm{in}$.).

Kochanowski, komponując Elegiarum libri quattuor, wyraźnie starał się - w myśl zasady varietas - możliwie najbardziej urozmaicić utwory o tematyce miłosnej. Zakres form i tematów w ramach gatunku jest tu spory - obok tzw. subiektywnych elegii, eksponujących „ja” liryczne, pojawia się elegia obiektywna wzorowana na Heroidzie 4 Owidiusza (I 2 - szalona namiętność prezentowana z punktu widzenia kobiety, Fedry), elegia aitiologiczna (I 15 - o powstaniu kopca Wandy), są też bukoliki miłosne (I 9, 11), epitalamion na ślub Andrzeja Dudycza (III 16), propemptikon opuszczającemu młodą żonę (IV 1, z wewnętrznym epylionem na temat mitologiczny: Ulisses i Penelopa) etc. To dążenie do zaprezentowania wielu możliwości widać także w obrębie jednej formy, jaką jest paraklausithyron. Co wydaje się warte podkreślenia, zwłaszcza w stosunku do prezentowanych wcześniej, o wiek starszych tekstów włoskich, utwory Kochanowskiego wyróżnia silna autotematyczność - dominująca w tekście refleksja na temat własnej twórczości. To zresztą typowa cecha poezji uczonej wieku XVI, wystarczy wspomnieć teksty o pokolenie starszego od Polaka Holendra, Janusa Secundusa (np. paraklausithyron z elegii II 5).

Przyjrzyjmy się bliżej dwóm paraklausithyrom polskiego poety. Początek elegii I 8 operuje nieco podobnym zestawem motywów, jak omawiany wiersz Landina Xandra II 7: bezsenność spowodowana chorobą miłosną, wyprowadzająca zakochanego nocą pod drzwi; skargi na nieczułość dziewczyny i pocie-

\footnotetext{
6o Przekład poetycki E. Buszewicz.
} 
szanie się, że ta kiedyś pożałuje dzisiejszej płochości; na koniec nadzieja na odzyskanie jej względów. Akcenty rozkładają się jednak inaczej.

Quid causae esse putem, nullum quod lumina somnum

Admittunt, nulla est quod mihi grata quies?

Cur pigri soles, cur nox tam longa videtur,

Idemque et corpus cordaque languor habet? [...

Morbus amor meus est, et tu poscentibus astris,

Tam formosa meo nata puella malo.

(Koch.El. I 8, 1-4, 7-8)

Jaka tego przyczyna, że sen na moje powieki

nie spływa, że odpoczynek żaden nie jest mi miły?

Czemu dni tak opieszałe i czemu noc tak długą się zdaje?

Dlaczego i ciało, i duszę jednaka słabość przenika?

[...]

Moją chorobą jest miłość, i ty, za gwiazd złym zrządzeniem

tak urodziwa dziewczyno, zrodzona na moje nieszczęście!

To wyznanie przechodzi w błaganie o litość - „Oszczędź! na chyłkiem kradzione słodkie rozkosze Wenery [furta Venris podstępy miłosne, to również jedno z elegijno-komastycznych słów kluczy] [...]/ oszczędź mnie, błagam, nie pozwól, by talent co ma cię ku gwiazdom/ wynosić, w żalu i trosce starzał się, marniał przedwcześnie!” ${ }^{6}$ (Koch.El. I 8, 11, 13-14). Deklaracja, że swą poezją przewyższyłby samego arcypoetę Orfeusza, słynącego tym, że słuchał go dziki zwierz, a drzewa i skały za nim podążały ${ }^{62}$, jest z jednej strony manifestem dumnej samowiedzy, z drugiej - zgrabnym nawiązaniem do topiki dura puella:

Carminibus victae quercus et frigida quondam

Saxa: tibi saxis cor erit asperius.

(Koch.El. I 8, 17-18)

Niegdyś dawały się pieśniom wzruszyć dęby, nieczułe kamienie - a twoje serce twardsze będzie od skały?

${ }^{61}$ „Parce tamen, per ego Veneris te dulcia furta, $[\ldots] /$ Parce, neque ingenium, te ferre ad sydera natum, / Frustra inter curas consenuisse sinas".

${ }_{62}$ Np. Ov.Met. XI, 1-2: „Carmine dum tali silvas animosque ferarum/ Threicius vates et saxa sequentia ducit [...]” („Gdyby takimi pieśniami tracki wieszcz lasy i dzikie zwierzęta, i skały prowadził za nim idące [...]”). 
Inny wariant wykorzystania postaci Orfeusza dla rozwinięcia tego motywu widzimy w kolejnej elegii I 12:

At mihi nec sylvas deducere montibus altis,

Nec trahere insuetas carmine cura feras:

Cura mihi est cantu teneram placare puellam,

Et duro affixas posti aperire fores.

(Koch.El. I 12, 17-20)

Lecz nie mnie prowadzić za sobą lasy z wysokich gór, ani pieśnią czarować nieoswojone, dzikie zwierzęta:

o to się staram, by śpiewem złagodzić delikatną dziewczynę i żeby otworzyć wrota przywarte do twardych odrzwi.

Zdaje się, że Kochanowski korzysta tu z fragmentu Propercjusza: ,illae iam sine me norant placare puellas, / et quaedam sine me verba diserta loqui” („one [tabliczki z wierszami] beze mnie umiały zjednać dziewczęta i wypowiadać beze mnie pewne słowa wymowne”, Prop. III 23, 5-6), zamieniając jednak wersję pisaną wierszy na wyśpiewywaną pieśn - ze względu na sytuację komastyczną. Słychać tu również echo wspomnianych na początku Owidiuszowych pochwał skuteczności działania elegii. Albo w polskiej wersji: „Słuchasz? Czyli mój głos nie może/ Dolecieć na twoje łoże? / Słuchajcie wy, nocne cienie, / I nieumowne kamienie!" (Koch.Pieśni I 21, 18-21), po czym pojawia się exemplum $\mathrm{z}$ dwoma mitycznymi pieśniarzami, Amfionem i Orfeuszem, poruszającymi kamienie, lasy i piekielne Furie. Często bowiem drzwi czy kamienny próg wydawały się „zamkniętemu na zewnątrz" amantowi bardziej skłonne do słuchania niż adresatka miłosnych skarg.

W elegii I 8 wątek autotematyczny zostaje rozszerzony: to skarga na czasy, w których sztuka doznaje wzgardy, a ceni się tyko tych, których cały talent i wdzięk mieści się w szkatule:

Illis aerati postes et ferrea cedunt

Limina, nec vigilum turba molesta canum est.

At me cum Musis vocalique improba Phoebo

Stare iubet clausas ante puella fores.

Me canis exagitat, me custos liminis arcet:

Si dedero, et custos, et canis ipse tacet.

(Koch.El. I 8, 23-28)

Dla nich stają otworem spiżowe wrota i żelazne progi, niestraszna im czujna psia zgraja. 
Mnie zaś wraz z mymi Muzami i śpiewnym Febem zuchwała dziewczyna każe czekać u zamkniętych drzwi.

Mnie pies zajadły odpędza, mnie stróż odgania od progu: jeśli im coś podaruję, i stróż, i pies zaraz ucichną!

W dalszej tyradzie, jaką pauper poeta głosi przeciw władzy pieniądza i sprzedajnej miłości, ciekawe jest odwrócenie motywu servitium amoris. W elegii to kochanek, choć człowiek wolny, zapewne szlacheckiego pochodzenia, przedstawiany jest jako niewolnik (nawet przykuty łańcuchem do drzwi) swojej pani (domina - określenie rangi społecznej, dominus to również właściciel niewolników; w istocie meretrix była zwykle niewolnica), jakby skazany na wieczną, dozgonną służbę w poniżeniu. Kochanowski sugeruje, że to kobieta za większą zapłatę gotowa jest sama oddać się do niewoli:

Heu dominum ingenua quam turpe est quaerere forma

Sponteque in alterius iura venire viri.

Fortunae vincti faciunt convicia servi,

Vos iuvat accepto munere iussa pati.

(Koch.El. I 8, 29-32)

Biada! Jak niecny to sposób, szukać pana kusząc pięknym ciałem, i poddać się z własnej woli pod władzę innego mężczyzny!

Niewolnik zakuty w kajdany złorzeczy swojej fortunie: wam zaś podarek wystarcza, by spełniać cudze rozkazy!

Po tej konstatacji Kochanowski rozwija dalej topiczny już temat niszczącego wszystko czasu (tempus edax). Jest tu jednak pewien element bardzo charakterystyczny dla sztuki renesansowej: skontrastowanie piękna młodości z brzydotą starości. $\mathrm{W}$ omawianym typie wypowiedzi poetyckiej dostrzec można bowiem topiczny zespół motywów: paraklausithyron połączony $\mathrm{z}$ opisem piękna dziewczyny porównanej do róży, który kończy się zastraszeniem dziewczyny nadchodzacą starością. Spośród jego różnych realizacji wymienić można utwór Strozzy, Qualis visa Anthia sedens sub umbra in Coppari agris (Eroticon I 3, 47-66), wiersz Pontana w finezyjny sposób opracowujący ten zespół motywów (nie elegijny, lecz w naprzemiennych dymetrach i trymetrach jambicznych) - Ad Faniam (Pont.Parth. I 4), około siedemdziesięciu lat później bogato i pięknie rozwinięty w elegii I 5 Janusa Secundusa (1511-1536), gdzie zresztą bardzo silnie podkreślony został wątek niesłabnącej sławy poety, która zwycięsko przeciwstawia się niepowodzeniom miłosnym elegika. 
Kochanowski musiał znać to połączenie motywów i świadomie tu umieścić (podobnie zresztą w odzie Ad Lycen), jednak jego wyraźnie klasycyzujący styl nie pozostawia miejsca na szersze rozwinięcie i pozostaje tylko ślad motywu, wpisany w szersze rozważania: „Non semper florentve rosae, florentve hyacinthi, / Et formae exitium fata dedere suum” („Nie kwitną wiecznie róże, nie kwitną hiacynty: / również urodzie losy naznaczyły koniec", Koch.El. I 12, 43). Zresztą polski poeta zmierza do zakończenia odmiennego niż w przytaczanych utworach, wzorowanego na Tibullusowej wizji szczęścia po grób.

Ciekawie poprowadzony wątek autotematyczny obecny jest również w elegii I 12. Kochanowski zaczyna wiersz zwrotem do przyjaciół - w komosach współbiesiadnicy wędrujący przez miasto mieli niekiedy odciągać nieszczęśnika od drzwi dziewczyny (por. też w elegii I 14 zwrot do przyjaciela, który w przeciwieństwie do wspomnianego nieszczęśnika potrafi ukrywać miłość, nie afiszując się z nią na ulicy, pod drzwiami). Do nich więc kieruje swe słowa zakochany - świadom swojego upadku i niewoli nierozumnej miłości (insipiens amor), której uległ. Jednak wszystkie dobre rady są na nic - Amor pozostaje na nie głuchy: „Sed surdis etiam dicitur auriculis./ Surdis, si moneas recte sin ocia laudes, / Audiet, et laetis annuet usque genis” („lecz także, mówią, uszy na wszystko ma głuche - / głuche na słuszne napomnienia: lecz jeśli chwalić rozkosze,/ wszystko usłyszy i skwapliwie potaknie", w. 4-5), a zresztą wszyscy podlegają tym prawom.

Jednakowoż zaraz po tym podkreślona zostaje kulturotwórcza rola boga miłości, który twardego, nieczułego Sarmatę („durum Sauromatam”) odciagnął od trudów wojennych („studiis belli”), by nauczyć pokojowych sztuk i słodszej nad wszystko muzy („Pacificasque artes dulcemque ante omnia Musam/ Perdocuit”, w. 13-14). Dzięki temu nie tylko zimna Tracja, ale i Sarmacja będzie mieć swego wieszcza. Po tej dumnej autoprezentacji następuje cytowane już odniesienie do Orfeusza. Odniesienie kontrastowe - nie dzikie zwierzęta i twarde kamienie będą adresatami jego pieśni, lecz delikatna dziewczyna. Ta deklaracja pociąga za sobą następną, sformułowaną w duchu recusatio. Nadzieja na powodzenie $\mathrm{w}$ miłości dzięki kunsztowi poetyckiemu prowokuje do wyrzeczenia się wszystkich innych tematów - poeta nie ma bowiem ambicji ani Orfeuszowych, ani militarnych:

Alter equis igitur candentibus, hoste subacto,

Late per populos conspiciendus eat 
Si non invito spectas me, Lydia, vultu,

Nulla mihi est victis gloria tanta Scythis,

Nulla, nec antiqui regnum florens Halyattis,

Quasque Asiae iactat frugifer orbis opes.

(Koch.El. I 12, 25-26, 29-32)

Niech inny więc na jasnych rumakach, rozgromiwszy wroga, jedzie, przez lud wszystek podziwiany [...

jeśli, Lidio, spoglądasz na mnie życzliwym okiem, nic mi po wielkiej sławie ze zwycięstwa nad Scytami,

nic, nawet kwitnące królestwo dawnego Alyattesa, ani bogactwa, w jakie tylko obfituje żyzna Azja.

To klasyczny topos recusatio - u Horacego i w elegiach zwykle pojawiający się jako odmowa pisania pod dyktando, w wysokich gatunkach, na poważne tematy epickie, heroiczne lub ku chwale władców (por. „alter dicat opus magni mirabile mundi...” - „Inny niech mówi o podziwu godnym powstaniu wielkiego świata...", Tib. III 7, 17), albo też odmowa poświęcania się intratnym zajęciom, jak żołnierka, kupiectwo czy zawody sportowe (por. początek elegii I 1 Tibullusa: „Divitias alius fulvo sibi congerat auro...” - „Niech kto inny gromadzi jasne złoto...” motyw częsty w polskiej, jak i łacińskiej twórczości Kochanowskiego). Alternatywne dla tych zajęć jest jedynie tworzenie pieśni miłosnych. Po odrzuceniu działań uznawanych za warte wysiłku następuje długi stoicki wywód dowodzący daremności podejmowania wszelkich trudów wobec zmienności fortuny i niepewności losów człowieczych. A zatem - czego już Kochanowski nie dopowiada, lecz wynika to z wcześniejszego tekstu tylko miłość zasługuje na to, by podjąć działanie.

Wspomnę jeszcze o dwóch motywach komastycznych pojawiających się w Elegiarum libri quattuor. Elegia I 14 opisuje charakterystyczny elegijny trójkąt miłosny: dziewczyna, poeta i ten trzeci, bogatszy (divus amator), który w dodatku był niewolnikiem, a wykupiwszy sobie wolność, wzbogacił się kradzieżą i morderstwem. Rzucane na niego kalumnie przechodzą w idylliczną wizję miłości w wieku złotym, gdy ludzie nie znali bogactw, a dziewczyna zadowalała się darem z jagód: „Felix prima aetas, cum luxus nescia pubes/Vitam inter sylvas duxit et inter agros” („O szczęsny pierwotny wieku, gdy młodzież, nie znając zbytku, / wiodła swój żywot wśród lasów i pośród pól!", w. 37-38). Fragment ten odwołuje się do opisu wieku złotego z Metamorfoz Owidiusza, i zapewne do passusu z Propercjusza 
(„felix agrestum quondam pacata iuventus, / divitiae quorum messis et arbor erant!...” - „Szczęśliwa [była] niegdyś spokojna młodzież wiejska, której całe bogactwo stanowiło żniwo i sad", Prop. III 13, 25-4063). Tęsknota za czystą, niesprzedajną miłością, związana z nurtem myślenia o pierwotnej czystości moralnej człowieka zjednoczonego $\mathrm{z}$ naturą, $\mathrm{z}$ czasów gdy nie było jeszcze władzy ani pieniądza, mocno zespoliła się $\mathrm{z}$ wzorcem miłości elegijnej i pastoralnej ${ }^{64}$, które wzajemnie na siebie wpływały, zarówno w okresie rzymskim, jak i w XVI-XVIII w.

Jeśli chodzi o kwestie moralne, w elegiach rzymskich, gdzie panuje amor furtivus, a zdrada i rozmaite furta veneris są elementami gry miłosnej, pojawia się często nie tylko trójkąt, ale i czworokąt miłosny. Do przechytrzenia bywa bowiem, prócz „męża” czy „opiekuna” dziewczyny, jeszcze kochanek konkurent (np. Tib. I 2). U Kochanowskiego aż tak skomplikowanego układu nie ma. W ogóle w renesansowych komosach nie zauważyłam relacji, w którą byłby uwikłany mąż. Postać taka pojawia się, ale jako szczęśliwy rywal: poślubiając go, dziewczyna porzuca dawnego amanta - i na tym jej związek z poetą się kończy. Może trzeba tłumaczyć to względami moralnymi - zdrada małżeńska w kontekście nowożytnym i chrześcijańskim ma zupełnie inny wymiar niż wśród wyzwoleńców rzymskich - zapewne, nawet w obrębie konwencji klasycznej, nie wypadało czynić takich aluzji, była to bądź co bądź poezja nie obsceniczna, lecz "uczona” (choć włoskie realizacje bywają nader frywolne - rzecz jasna, bardziej te epigramatyczne, niskie, niż elegijne, czyli w gatunku średnim). Inne wytłumaczenie to „realizm społeczny” - jeśli nawet kurtyzany w XV czy XVI w. były czyimiś żonami, to lepiej było tego nie sugerować (włoska literatura $\mathrm{z}$ epoki, np. pisane w stylizowanym dialekcie chłopskim jednoaktówki Ruzzantego (właśc. Angelo Beolco) ${ }^{65}$, przytacza wiele przykładów zamężnych kobiet wiejskich, które uciekały przed nędzą do miasta i żyły z nierządu).

Kochanowski wybiera jeszcze inną antyczną opcję urozmaicającą motyw - ten trzeci to zazdrośnik, który może zapeszyć czy - w sensie magicznym - zauroczyć i przez to zniszczyć

${ }_{63}$ Inne jeszcze similia antyczne zestawione przez G. Franczaka - zob. edycja internetowa.

${ }^{6}$ Por. G. Urban-Godziek, Homo bucolicus. Wzorce cztowieczeństwa w europejskiej poezji pastoralnej $i$ ich polskie realizacje w XVI $i$ XVII w., w: Humanizm. Historie pojęcia, red. A. Borowski, Warszawa 2009, s. 419-422 oraz w kontekście pastoralnej poezji miłosnej, również elegijnej - s. 439-445.

${ }_{6}$ Zob. Discorso di Ruzzante che era venuto dalla guerra lub Bilora (1528) w wersji polskiej: Łasica, w: Teatr wenecki, przekład, posłowie i opracowanie J. Adamski, Kraków 1980. 
szczęście kochanków. Na niego śle poeta złorzeczenia mające moc sprawczą („Perfidus ille, meo quicunque invidit amori, / Iratos habeat, quicquid aget, superos” - „Zdrajcą jest ten, kto pozazdrościł mi kochanki - / niech, cokolwiek by robił, ściga go gniew bogów”, Koch.El II 5, 11-12). Dalej następuje charakterystyczne zapewnienie pilnego ucznia Wenery o stałości, której nie skruszy żadna przeciwność:

Me Venus edocuit quosvis sufferre labores Et mihi iam pridem nil in amore novum est.

Edidici hybernis pluviam fundentibus Austris

Dormire ingratas frigidus ante fores

Et mihi promissas potiori cedere noctes,

Et lachrymas siccis dissimulare genis.

Lydia, te propter nihil est, quod ferre recusem,

Seu faveas, seu tu sis inimica mihi.

(Koch.El. II 5, 21-28)

Mnie Wenus nauczyła, jak znosić wszelkie cierpienia,

i od dawna nic w sprawach miłosnych nie jest mi obce.

Nauczyłem się spać zziębnięty u niewdzięcznych wrót,

gdy zimowy Auster tnie deszczem,

umiem innemu szczęśliwcowi oddać noce, które mi obiecano, i sprawić, by łzy nie zrosiły suchych policzków.

Nie ma rzeczy, Lidio, której wzbraniałbym się znieść dla ciebie, wszystko jedno, czy sprzyjasz mi, czy jesteś mi wroga.

\section{Paraklausithyra polskie Jana Kochanowskiego}

Wymienione trzy utwory z Pieśni Kochanowskiego zostały już niegdyś zakwalifikowane jako paraklausithyra i poddane anali$z_{i e}^{66}$. Włączenie ich do niniejszych rozważań nad paraklausithyronem elegijnym wydaje się również zasadne, jak dowodnie bowiem wykazała Zofia Głombiowska ${ }^{67}$ - erotyki (obecne w dość konsekwentnie horacjańskim zbiorze Pieśni) czytane kolejno układają się w przejrzystą historię miłosną opartą na modelu elegijnym (któremu teoretyczny opis dał wspomniany Scaliger).

${ }^{66}$ Zob. Z. Głombiowska, op.cit., s. 215-222; R. Grześkowiak, Jan Kocbanowski przed zamkniętymi drzwiami. Paraklausitbyron w erotykach , ksiagpierwszych" Pieśni, w: Wyobraźnia epok dawnych: obrazy - tematy - idee. Materiaby sesji dedykowanej Profesorom Jadwidze i Edmundowi Kotarskim, red. J.K. Goliński, Bydgoszcz 2001, s. 133-151.

${ }_{67}$ Z. Głombiowska, op.cit., s. 211-223. 
Wymienione już trzy polskie pieśni z Ksiag Pierwszych (21, 23, $25)$ to utwory niezwykle interesujące w przedstawionym tu kontekście. Są znacznie oszczędniejsze niż elegijne, dzięki czemu ich struktura komastyczna jest łatwiej dostrzegalna niż w tekstach łacińskich. Pisane są wierszem ciągłym - pieśniowy ośmiozgłoskowiec w pierwszym i trzynastozgłoskowiec, który mógłby zastępować dystych elegijny, w pozostałych. Pierwodruk i rozkład treści sugerują jednak liryczny podział na strofy. W ten sposób teksty maskują elegijny wzorzec, niejako usprawiedliwiając tym włączenie do zbioru pieśni. Niezależnie od metrum zwraca tu uwagę lekkość pieśniowa i świetne wyważenie lirycznie, zwłaszcza $\mathrm{w}$ pieśni 21 . Nie zagłębiając się zanadto $\mathrm{w}$ analizę, można by te teksty zakwalifikować do nowożytnej serenady - gdyby nie fakt, że zbudowane zostały na łatwo rozpoznawalnych wzorcach rzymskich (bogate similia antyczne przedstawia komentarz Marii Cytowskiej do edycji Pieśni w Wydaniu Sejmowym). Jest też zajęciem frapującym śledzenie wyborów translacyjnych mistrza z Czarnolasu, który starał się w polszczyźnie znaleźć najlepszy ekwiwalent terminów doskonale znanych czytelnikom poezji klasycznej, głównie elegijnej (w niniejszym studium kilkakrotnie wskazano takie rozwiązania).

W tych trzech tekstach zawarł Kochanowski większość typowo komastycznych i elegijnych motywów. Mamy tu liryczny lament kochanka czuwającego aż do świtu pod drzwiami dziewczyny „cierpiąc nocne niepogody” (z uczoną inkrustacją mitologiczną) w pieśni I 21 i, wewnątrz monologu bramy, w I 25; w 23 i 25 pojawia się personifikacja drzwi; renuntiatio amoris w I 23, z klątwą rzuconą na wrota; wreszcie lament bramy spotwarzanej przez „sprosnych pijanic”, z klasycznym diffamatio - osławieniem obyczajów pani domu - parafraza elegii I 16 Propercjusza w pieśni I 25 Kochanowskiego. Uderza przy tym doskonała znajomość tematu i arcyzgrabne rozwiązania leksykalne. I gdyby nawet elegie mogły znużyć współczesnego niecierpliwego czytelnika długością czy zniechęcić niekiedy trudno dziś akceptowalną nagłą zmianą tematów (zaznaczmy jednak, że na tle innych elegii z epoki są one bardzo dynamiczne), to myślę, że i w krytyce współczesnej pieśni ujdą cało...

Włączenie do Pieśni erotyków układających się w charakterystyczną dla cyklów elegijnych historię miłosną wydaje się również świadectwem odrywania się elegijności od gatunku. Elegijności, czyli elegijnego modelu przeżywania miłości - naznaczonego melancholią, tęsknotą, pełnego wielkich nadziei i gorących, niezaspokojonych uczuć, euforii i rozpaczy. To model, który ewoluował zgodnie z duchem epoki, model miłości wbrew roz- 
sądkowi oraz podziałom społecznym, miłości mimo braku szans na spełnienie, wiernego oddania na wieczną służbę, w niewolę pani, model miłości z oddali ${ }^{68}$, miłości do „anioła” - niewiasty doskonale pięknej duchowo i cieleśnie, a przez to idealnej i nieosiągalnej, miłości niekończącej się nawet długo po śmierci; wreszcie - uczucia sentymentalnego, delikatnego i nieśmiałego i jednocześnie artystycznie wyrafinowanego, albo ekspresji artysty, który nigdy nie może znaleźć spokoju, ukojenia i spełnienia.

Wydaje się, że dodatkowym pożytkiem płynącym z zaprezentowanych badań, sięgających $\mathrm{w}$ głąb historii jednego motywu czy formy literackiej, jest otwieranie nowych perspektyw odczytu dzieł dobrze znanych. Oglądane razem łacińskie i polskie paraklausithyra Kochanowskiego, nadto umieszczone w kontekście realizacji klasycznych i renesansowych, z których większość musiał znać, dają jeszcze jedną możliwość przyjrzenia się warsztatowi poety, ewolucji jego myślenia o gatunkach lirycznych i programowi literackiemu. Dowodzą, że łacińska twórczość Kochanowskiego rozwijała się bardzo dynamicznie w okresie czarnoleskim, że z pewnością wtedy musiał mieć dostęp do nowości literackich z Południa i Zachodu. Kochanowski, dla którego jednym $\mathrm{z}$ nadrzędnych celów było stworzenie języka polskiej poesia docta, kształtował go na wzór klasyczny, pracując nad kolejnymi formami literackimi i tematami w obu językach, dla każdego z nich znajdując odpowiednie środki, nadając właściwy językowi i jego tradycji kształt.

Odwołanie się ojca polskiej poezji uczonej do formy, która $\mathrm{w}$ następnych dwóch, a nawet trzech wiekach - w postaci serenady - osiągnie ogromną popularność, świadczy również o jego wyczuciu pulsu kultury. Zapewne wspomniane utwory z Pieśni tę popularność na terenie siedemnastowiecznej Polski wzmogły, dając niewątpliwie wzór stylu i języka (podobnych wzorów liryki miłosnej poezja XVII w. miała nader niewiele). Pieśń u drzwi dziewczyny, pod oknem czy balkonem, odrywając się od pierwotnej antycznej formy ${ }^{69}$ i przenikając do rozmaitych rodzajów

${ }_{68}$ Por. oksytańskie amor de lonb z poezji trubadurów.

${ }^{69}$ Klasyczna forma paraklausithyronu jest jednak wciąż żywotna - w dodatku w postaci śpiewanej. Świadczą o tym powstałe w drugiej połowie XX w. doskonale świadome nawiązania do tej formy lirycznej, jak choćby piosenka Jeremiego Przybory Pod twoim oknem co nocy stoję..., wykonywana przez Wiesława Michnikowskiego (1961), a następnie przez Grzegorza Turnaua (2004), czy szlagiery Boba Dylana Temporary Like Achilles (1966) oraz Standing in the Doorway (1997). 
literackich, dramatycznych i muzycznych, na stałe też weszła do naszej wyobraźni i kultury. I choć w Polsce niezmiernie rzadko dziś śpiewa się tęskne pieśni pod oknem dziewczyny czy chodzi z muzykami w konkury - wciąż jest to czytelne zachowanie o charakterze archetypicznym. Być może, gdyby jakimś cudem wzrosła kultura muzyczna Polaków, czuła dusza słowiańska odnalazłaby się w tej pięknej, uszlachetnionej formie antycznego paraklausithyronu...

\section{GRAŻYNA URBAN-GODZIEK}

\section{Elegy on a threshold. Classical heritage of the paraklausithyron motif in the Renaissance elegiac poetry (usque ad Ioannem Cochanovium)}

Paraklausithyron - a lover's lament at the closed door of the beloved, desiring entry, is a very old literary and musical motif, deriving from the archaic genre of komos, characteristic for Greek comedy. Paraklausithyron was successfully adopted by Roman literature to become one of the basic motifs of love elegy in the Roman Empire of Augustan times. The present study explores the history of the motif and outlines the main features of its Roman variety. Then, its reception in Italian elegiac poetry of the Renaissance period is presented, and, within this context, the use of the motif in elegies written in Latin and Polish by Jan Kochanowski is discussed. Vigils at the beloved one's door are presented here as an essential element of an elegiac confession of love containing a characteristic line of arguments and distinguishable key words which, in the course of time, came to substitute the motif and the confession of love itself. The motif also pervaded other forms of modern lyric love poetry, in particular the serenade; just as the elegiac sense of love initiated the sentimental trend in European poetry.

Key words: paraclausithyron, exclusus amator [shut-out lover], serenade, Neo-Latin poetry, Jan Kochanowski, Giovanni Pontano, Cristophoro Landino.

GRAŻYNA URBAN-GODZIEK - doktor, polonistka i neolatynistka, adiunkt w Katedrze Historii Literatury Staropolskiej na Wydziale Polonistyki UJ. Od 2004 r. prowadzi tam interdyscyplinarny Ośrodek Badań nad Renesansem (http://humanitas.filg.uj.edu.pl). Kieruje zespołem przygotowującym edycję krytyczną łacińskich dzieł Jana Kochanowskiego (wersja internetowa: http://neolatina.bj.uj.edu.pl). Jej najnowsze badania skupiają się na historii toposów i motywów europejskiej liryki od antyku po kres nowożytności, obejmują zagadnienie wzajemnego oddziaływania wczesnonowożytnej poezji łacińskiej i wernakularnej. Autorka książki Elegia Renesansowa. Przemiany gatunku w Polsce i w Europie (2005) oraz licznych artykułów, 
82 Grażyna Urban-Godziek

m.in. Magistri basiorum - neoplatońskie wariacje na temat katullańskich pocałunków. Od Giovanniego Pontana do Jacobusa Pontanusa (2009) czy „Treny” Jana Kochanowskiego wobec włoskiej tradycji funeraliów poświęconych dziewczętom (Giovanni Boccaccio, Giovanni Pontano i inni) (2008).

e-mail: grazyna.urban-godziek@uj.edu.pl 